\title{
La historieta y la representación de la masacre. Algunas hipótesis a partir del uso de la metáfora del dolor animal.
}

\author{
The comic and the representation of massacre. Some hypothesis \\ derived from the use of the animal suffering metaphor
}

José Emilio Burucúa ${ }^{1}$ y Nicolás Kwiatkowski ${ }^{2}$

RESUMEN

Este artigo estuda oito quadrinhos produzidos em diferentes circunstâncias, alguns deles obras de ficção, outros se referindo a fatos reais. Ele tenta descobrir as relações entre a representação do massacre e genocídio eo uso de metáforas de animais eo sofrimento humano.

Palabras Clave: Massacre. Genocidio. Representação. Sofrimento. Animalização História da cultura. Estudos do genocidio

ABSTRACT

This article studies eight comics produced in different circumstances, some of them works of fiction, others refering to real events. It attempts to discover relationships between the representation of massacre and genocide and the use of metaphors of animal and human suffering.

Keywords: Massacre. Genocide. Representation. Suffering. AnimalizationHistory of culture - Genocide studies.

La alusión al padecer devastador de los hombres mediante referencias al sufrimiento animal es muy antigua. Nuestra intención es explorar el modo en que las viñetas serias hicieron lugar a esa red de comparaciones y metáforas. Específicamente, nos interesa estudiar tales usos

1 Escuela de Humanidades, UNSAM.

2 CONICET, UNSAM-IDEAS. 
en relación con las masacres de la modernidad y los genocidios del mundo contemporáneo. Ya en la Mesopotamia de comienzos del segundo milenio antes de Cristo, el poema de Gilgamesh hace resonar en los animales objeto de la caza -el oso, la hiena, el tigre, la pantera, el leopardo, el león, el ciervo y el toro- el llanto o el dolor provocados por la muerte de Enkidu en el ánimo del protagonista principal de la historia. (SANDARS, 1977) La imagen de la leona herida en los bajorrelieves de Nínive, del siglo VI a.C., parece multiplicar el efecto de la identificación de los padecimientos. Si se compara esta figura con la de otros animales atacados en el mismo conjunto, no hay duda de que el felino, que ha perdido la movilidad de su tren inferior debido a los flechazos de los cazadores que le atravesaron la médula, se encuentra en el estado más radical de la indefensión y el dolor. [Imagen 1$]^{3}$

La religión cristiana colocó la identificación explícita entre los dos sufrimientos de los que hablamos en el centro de su acto sacrificial y conmemorativo por excelencia, ya que la misa culmina en la invocación al Agnus Dei, el cordero místico que asume los males de la humanidad para salvarla mediante el sacrificio de sí mismo. ${ }^{4}$ Es más, en la leyenda de la visión de San Eustaquio, un ciervo, víctima animal de la caza, se funde con el Cristo en la Cruz que se despliega entre sus cuernos y Jesús habla por boca del bruto, según narra la leyenda de aquel santo en la obra de Iacopo da Varagine. (DE VORAGINE, 1967, v. 2, p. 306-309) Una pintura de Pisanello y un aguafuerte de Durero ilustran el episodio. [Imagen 2] Por otra parte, entre varios textos de William Shakespeare que apelan al recurso, en la comedia Como gustéis, uno de los nobles del séquito del duque narra la agonía de "un pobre ciervo extraviado, víctima de la puntería de un cazador [...] Tales gemidos lanzaba el pobre animal que su vestido de cuero se hinchaba casi hasta estallar y esas lágrimas redondas corrían una a una por su inocente nariz, en piadosa caza". (SHAKESPEARE, 1951, p. 1208). También en el mundo de la fábula, usada para representar una experiencia religiosa, el judaísmo de la temprana modernidad utilizó la figura de la liebre, animal inocente acosado por el águila cazadora, como símbolo del pueblo de Israel y de sus infortunios, cosa que descubrimos en la decoración pictórica del techo de la sinagoga de Hodorov, Ucrania (1714). (HOROWITZ, 2001). [Imagen 3]

En octubre de 1838, Alfred de Vigny compuso el famoso poema La muerte del lobo. El noble autor ha dado muerte a un lobo que lo miró en el momento mismo de expirar. Su reflexión se explaya como sigue: “Qué vergüenza siento de nosotros, débiles como somos! / De qué manera debemos abandonar la vida y todos sus males, / sois vosotros quienes lo sabéis, animales sublimes. / Al ver lo que hemos sido en la tierra y lo que abandonamos, / sólo el silencio es grande; todo el resto es debilidad". De Vigny imagina que el lobo le habla y le dice: "Gemir, llorar, rogar, es todo igualmente cobarde. / Haz con energía tu trabajo largo y pesado / en el camino donde la suerte quiso llamarte, / luego, como yo, sufre y muere sin hablar." (VIGNY, 1864). Ecos indudables de esa muerte encontramos en Estival, de Rubén Darío, publicado en 1888: "El tigre sale huyendo, / y la hembra queda, el vientre desgarrado. / ¡Oh, va a morir!... Pero antes, débil,

\footnotetext{
3 - Las imagenes estan en el fin.

${ }^{4}$ Juan 1,29. "He ahí el Cordero de Dios, que quita el pecado el mundo."
} 
yerta, / chorreando sangre por la herida abierta, / con ojo dolorido / miró a aquel cazador, lanzó un gemido /como un jay! de mujer... y cayó muerta".

Ya en el siglo XX, el cinematógrafo echó mano de la metáfora sin reposo. Por ejemplo, la película Ascención, de Larisa Shepitko, (Voskhozhdeniye, 1977) recrea la experiencia de los partisanos que lucharon contra el nazismo en la Bielorrusia ocupada durante el invierno de 1942. Dos de los patriotas emprenden una misión relámpago en busca de alimentos. Logran hacerse de una vaca y huyen rumbo al bosque donde se ocultan sus compañeros, pero son sorprendidos por una patrulla alemana que dispara a mansalva. La cámara muestra en primer lugar al animal agonizante que nos prepara para la visión siguiente de los hombres heridos. Entretanto, en Missing, de Costa-Gavras, estrenada en 1982, Beth Horman, la esposa del desaparecido, queda involuntariamente atrapada en las calles de Santiago durante el toque de queda y no puede regresar a su casa. Se refugia en un umbral, desde donde ve pasar un espléndido caballo blanco que galopa desbocado en el boulevard, perseguido por un grupo de soldados que disparan al aire. El pánico del animal representa el pavor que experimentaban las víctimas humanas de los golpistas chilenos. Dos décadas más tarde, la fantasmagórica autobiografía de Guy Maddin, $M y$ Winnipeg (2007), apeló dos veces a nuestra forma de unificación de imágenes y sentidos. En primer término, cuando la hermana del cineasta regresa de una salida nocturna y relata que atropelló un ciervo con su auto, la madre asocia de inmediato la inocencia del animal muerto con la virginidad perdida de su hija, y deduce que la joven ha tenido esa misma noche su primera experiencia sexual. En segundo lugar, Maddin incluye en su propio rodaje un presunto documental de 1926 en el que se ha registrado la muerte por congelamiento de una tropilla de caballos que ha caído al río helado en un intento por escapar del incendio desatado en el hipódromo de Whittier Park. El dolor de los animales, símbolo del desasosiego de Maddin quien no puede escapar de su ciudad, se ve duplicado por la indiferencia de los hombres, que llega al extremo de convertir el sitio del drama en un lugar de esparcimiento. Los jóvenes de Winnipeg flirtean entre las cabezas transfiguradas de los equinos, increíbles prefiguraciones (si acaso el documental fuera verdadero, citas, mejor, si no lo fuera) del caballo transido del Guernica y de las cabalgaduras congeladas en la guerra de Finlandia descriptas por Curzio Malaparte en una página alucinada de su libro Kaputt, de 1943. Más aún, la historia de la muerte de los caballos en el film de Maddin es relatada mediante un dibujo animado: se trata también de una viñeta seria. [Imagen 4]

Creemos que este acercamiento a la representación del dolor animal-humano puede introducir una variable nueva en nuestro largo registro de las fórmulas destinadas a describir masacres y genocidios, sobre todo en relación con los géneros de la historieta, donde ya analizamos el caso de Maus desde esta perspectiva. (BURUCÚA, 2006, 2010). Es hora de que examinemos éste y otros cartoons a la luz del símil que acabamos de presentar. Nuestro orden de exposición tendrá en cuenta la diferencia entre obras de ficción y representaciones de hechos realmente acontecidos. Dentro de cada una de estas categorías, las series se disponen según el 
grado de amplitud e intensidad, de menor a mayor, que alcanza la superposición de los sufrimientos.

\section{a. Obras de ficción}

\section{The Book of Genesis}

En 2009, R. Crumb publicó El Libro del Génesis Ilustrado, una historieta sistemática que despliega el texto completo del primer libro de la Torá, exasperada versión iconográfica de la acción divina y humana desde la creación del mundo hasta la instalación de los hermanos de José en Egipto. (CRUMB, 2009). La imagen de un Yahvé riguroso, exigente, a menudo despiadado, lejos del Dios amoroso de los profetas, del Cantar de los Cantares y, más todavía, de los Evangelios, es la que predomina en toda la viñeta. Desde el punto de vista del tema que indagamos, nos interesan los cuadros dedicados al Diluvio, historia de castigo y redención de hombres y animales, obra de una divinidad terrible, en buena medida arbitraria y finalmente compasiva. Pero ¿cómo justificaremos la destrucción de los animales a partir de una culpa y de una responsabilidad puramente humanas? Los Padres de la Iglesia ya se habían hecho esta pregunta que aquí vemos volcada al cuadro de la tempestad donde hombres y animales aúllan y sufren por igual. Aquellos grandes teólogos respondieron mediante la noción de la cura vitae, es decir, la idea de que Dios decidió enviar la inundación tras un cuidado previo de todas las especies vivientes, una preservación actuada en el interior del arca. (BURUCÚA, 2011). El justo Noé fue el actor principal de semejante drama salvador, aunque también fue necesaria una intervención divina adicional, tal vez bajo la forma de un "impulso de los ángeles", para introducir las parejas de animales en el arca, sacarlas de allí más tarde y repartir su simiente por toda la Tierra. En los cuadros respectivos que dibujó Crumb, se advierte la pesadumbre que afecta a los brutos en el momento del ingreso y la libertad gozosa que ellos mismos demuestran durante el veloz abandono del arca tras el Diluvio. La cara de Dios, magnífica, severa si no terrible, abre y cierra las secuencias de los capítulos 7 y 8 que narran el episodio. El sufrimiento animal y humano ha tenido por finalidad la instauración de un orden agrícola y civilizatorio a cargo de Noé y sus descendientes en la Tierra, quienes habrán de respetar el anatema lanzado por Yahvé contra el asesinato entre semejantes y garantizar el reinado de la concordia. [Imágenes 5 y 6] 


\section{El Eternauta}

La más famosa historieta argentina, cuya historia ha explicado en detalle el último libro de Laura Vázquez (2010), contiene pasajes donde resulta posible reconocer aspectos de nuestro topos que, si bien engarzados en una épica visual derivada de la cinematografía bélica, introducen algunos matices destacables en el asunto. (OESTERHED, 1998). Por ejemplo, el caballo de tiro muerto con el que Juan Salvo se cruza en su primera excursión al exterior de la casa, duplica el cadáver de Polsky, primera víctima de la nevada fatal entre los amigos del protagonista. [Imagen 7] Pero no sólo son comunes al hombre y los animales la muerte y el dolor, sino la capacidad de resistencia y el propósito de permanecer como rescoldos últimos de la vida, tal cual se observa en la aparición inesperada de tres pollitos en la cocina donde se produce la muerte del primer "mano". [Imagen 8] Pocas páginas más adelante, este personaje, quien había sido enemigo feroz de los seres humanos hasta ese momento, alcanza una nueva cota del sufrimiento cuando, al morir, entona la "canción incomprensible de ritmo extraño" que Franco toma por un canto de cuna. También el "mano" que se interpone a la huida de nuestros aventureros en el subterráneo termina anonadado por el descubrimiento de Favalli acerca de la glándula del terror y su muerte permite que se manifieste la caridad heroica de Franco, quien lleva a su enemigo moribundo al exterior para que expire a su gusto, "de cara al cielo" y mirando las estrellas. "Un instante antes [Salvo] había admirado la suprema inteligencia de Favalli. Lo que ahora sentía por la grandeza de ánimo de Franco el tornero no era admiración. Era mucho más que eso. Era emoción". [Imagen 9] De manera equivalente, aprendemos que los autómatas humanos y los gurbos son manipulados por el artilugio del teledirector con el que los "ellos" dirigen la voluntad de hombres y monstruos. No sería caprichoso decir que la historieta ha planteado un destino común de las especies del universo bajo la égida del sufrimiento al que se opone la resistencia humana.

\section{b. Historias reales}

\section{Safe Area Gorazde. The War in Eastern Bosnia 1992-95}

Entre 1992 y 1995, la guerra de Bosnia hizo reaparecer en Europa escenas que se imaginaban enterradas en la historia de la Segunda Guerra Mundial. El conflicto por la desintegración de Yugoslavia causó decenas de miles de muertos, más de un millón de desplazados y una masacre, en el enclave de Srebrenica, que fue juzgada como genocidio por un tribunal penal internacional. Joe Sacco viajó a fines de 1995 al lugar de esos hechos y publicó, cinco años más tarde, un impresionante cartoon-reportaje que lleva el título de este apartado. (SACCO, 2000). En verdad, toda la historieta dispone sus secuencias a partir del modelo de la cinematografía documental, al mismo tiempo que suele subrayar el parentesco con la fotografía 
en los cuadros individuales. De las fórmulas que hemos identificado en la larga historia de la representación de las masacres - la cacería, el infierno y el martirio-, Sacco ha echado mano y extendido la metáfora infernal a la hora de historiar los ataques de los serbios en la ofensiva de 1994. [Imagen 10] Al infierno se suma claramente la referencia al martirio, que permite realzar la inocencia de las víctimas en las expresiones de los rostros de los heridos, pero esa fórmula alcanza su clímax en la escena de los fusilamientos masivos de musulmanes ante fosas comunes en Srebrenica. [Imágenes 11-12] La única nota de convergencia y resonancias entre padeceres de animales y hombres se produce en la representación de los desplazamientos forzados de refugiados bosnios con sus rebaños. [Imagen 13]

\section{Palestine}

El Informe Goldstone fue el reporte final de una comisión, presidida por Richard Goldstone y creada por el Comité de las Naciones Unidas para los Derechos Humanos (UNHRC por sus siglas en inglés) con el fin de investigar los abusos ocurridos en la Franja de Gaza durante el conflicto palestino-israelí de 2008-2009. La mejor forma de resumir brevemente las conclusiones del documento es que, para el comité, tanto Hamas como el estado de Israel han sido culpables de violaciones a los derechos humanos y a los derechos del niño, así como de crímenes de guerra y crímenes contra la humanidad. Se incluyen entre ellos el ataque intencional a poblaciones civiles, el uso de escudos humanos por parte de ambos contendientes, la privación de derechos políticos y básicos (como el agua o el alimento), el ocultamiento de esas violaciones, etcétera. El informe fue aprobado por el comité el 16 de octubre de 2009. (HUMAN RIGHTS COUNCIL, 2009). Llama la atención que un reporte de esa naturaleza contenga una descripción tan vívida de la experiencia de alienación mutua y de deshumanización recíproca que afecta por igual a las partes en pugna. Se cita, por ejemplo, la declaración del psiquiatra palestino Iyad Sarraj, quien sostuvo que "los palestinos, a los ojos del soldado israelí, no son seres humanos iguales a él. En ocasiones [...] incluso se convierten en demonios. [...] Esta cultura de la demonización y la deshumanización lleva a un estado de paranoia." El mismo testigo insistió en que, como palestinos, "consideramos en general demonios a los israelíes, lo que hace posible que los odiemos, por lo tanto lo que hacemos es una reacción, y también decimos que los israelíes sólo pueden comprender el lenguaje del poder. Decimos de los israelíes lo mismo quie ellos dicen de nosotros." ${ }^{5}$ Por su parte, el profesor israelí Ofer Shinar expresó ideas semejantes: "el problema de la sociedad israelí es que, como consecuencia del conflicto, la sociedad de Israel se ve a sí misma

\footnotetext{
5 - "The Palestinian in the eyes of the Israeli soldier is not an equal human being. Sometimes [...] even becomes a demon [...]" This "culture of demonization and dehumanization" adds to a state of paranoia." "As Palestinians, "we look in general to the Israelis as demons and that we can hate them, that what we do is a reaction, and we say that the Israelis can only understand the language of power. The same thing that we say about the Israelis they say about us" Human Rights Council (2009, p. 528-529).
} 
como víctima y, en buena medida, eso justifica su actividad y vuelve muy difícil que la sociedad se mueva y sienta que puede ver que del otro lado también hay víctimas. Creo que ésta es la mayor tragedia del conflicto y que es tremendamente difícil superarla. [...] El sentimiento de ser una víctima es algo que caracteriza a ambos lados". ${ }^{6}$

En rigor de verdad, ya en 2001 una historieta de Joe Sacco (2007), que manifestaba simpatía con la causa palestina, se hacía eco de los sufrimientos de ese pueblo y procuraba explicar la intifada sobre esas bases, dio una respuesta, aunque parcial, a la perplejidad de fondo expresada por los testimonios incluidos en el informe Goldstone. Si bien Sacco se ocupó de narrar las peripecias del conflicto ubicado en el territorio de Palestina y, por lo tanto, el dolor aparece representado sólo en las multitudes y los personajes árabes, la humanidad común a las naciones en pugna se desprende de los retratos de la ira que a ambas afecta. Por más despiadados que los israelíes hayan sido mostrados en la viñeta Palestine, en ningún momento ellos se asemejan a animales o autómatas. En todo caso, la página dedicada a "A Palestinian Joke" animaliza al pueblo palestino mediante su identificación con un asno indefenso que sufre los apremios de un agente secreto del Shin Bet, quien intenta hacerlo confesar que es, en realidad, un conejo y no un burro. [Imágenes 14-15]

Pese a que en la plancha que acabamos de describir el sufrimiento animal es metáfora del humano, no es esta fórmula la que predomina en el comic. Al contrario, el padecer es polimórfico y solamente humano, especialmente intenso cuando lo expresan las mujeres de todas las edades y condiciones. Sean víctimas ellas mismas o se encuentren desgarradas por el dolor de perder a sus hijos y maridos, las facciones, los gestos, las posturas del cuerpo transmiten todas las variantes imaginables de esa emoción entre la angustia exteriorizada en un grito y la melancolía. [Imagen 16] El close up, la visión cenital o la figura solitaria colocada en el fondo de una perspectiva son los recursos salientes del corpus de procedimientos empleados para construir el mundo afectivo de la historieta, su horizonte patético en términos warburguianos. Las vistas de multitudes abigarradas en espacios abiertos son, por el contrario, el vehículo de la tenacidad, de la fuerza y de la resistencia pacífica o violenta a la presión y el abuso. [Imágenes 17-18-19]

En 2008, Rupay, una historieta de Luis Rossell, Alfredo Villar y Jesús Cossio, utilizó algunos recursos estéticos semejantes a los de Palestine con el fin de describir la violencia política en Perú entre 1980 y 1984. (ROSSELL, 2008). Vistas cenitales, close ups, intensidad expresiva, la inclusión de la fórmula del martirio son parte del repertorio del libro latinoamericano. En el núcleo de la narración, reaparece nuestro topos. Los militares peruanos aterrorizan a los pobres campesinos de Chungui, una aldea andina. Un capitán muestra lo que el ejército planea hacer a

\footnotetext{
${ }^{6}$ - "Israeli society's problem is that because of the conflict, Israeli society feels itself to be a victim and to a large extent that's justified and it's very difficult for Israeli society to move and to feel that it can also see the other side and to understand that the other side is also a victim. This I think is the greatest tragedy of the conflict and it's terribly difficult to overcome it. [...] you should be able to see that the feeling of being a victim is something that characterizes both sides." Human Rights Council (2009, p. 529).
} 
los miembros de la guerrilla. Compara a los comunistas con perros e insta a los campesinos a matar animales como práctica previa para el asesinato de los rebeldes. Un soldado ejemplifica el procedimiento, al tiempo que el capitán grita: “iTraicionar a la patria es como faltarle a la madre! ¡Quien hace eso es criminal! ¡Abran esos animales!”. Más tarde, el jefe del escuadrón obliga a un campesino a repetir la operación asesina. El pobre hombre, quien teme por su propia vida, mata a la bestia, aunque al hacerlo se pregunta: “¿Por qué matar al pobre animalito?”. Tras anunciar que "aquí está prohibido tener pena", los militares obligan al campesino a comerse las entrañas del perro. [Imagen 20]

\section{Maus}

El célebre comic que Art Spiegelman presentó en dos partes entre 1973 y 1986 ha colocado en el centro mismo de su historia y estilo la metaforización de la experiencia humana en términos animales. (SPIEGELMAN, 1994). Maus reeditó el antiquísimo género de la fábula para contar el horror de la Shoah, esto es, convirtió en animales a los actores colectivos del genocidio judío en la Europa de la Segunda Guerra Mundial -víctimas, perpetradores, testigos, by-standersLos judíos fueron transformados en ratones, los alemanes y nazis en gatos, los polacos en cerdos, los norteamericanos en perros y así siguiendo. La elección debió de apoyarse en las tradiciones de la sátira en imágenes que se remonta, por lo menos, a los siglos XVI y XVII, cuando las convulsiones sociales de la Alemania de la Reforma y los avatares de la Guerra de los 30 Años hallaron una forma de representación en la enemistad perenne de ratones y gatos. [Imagen 21] Digamos que, en aquellos momentos, el papel de los roedores solía ser el de las víctimas pero, también, el de los beneficiarios de una inversión que castigaba a los soberbios y reivindicaba a los débiles (campesinos y protestantes contra señores en el siglo XVI, franceses contra españoles e imperiales en el siglo XVII). (BURUCÚA, 2007, p. 66-67). De todas formas, la viñeta de Spiegelman tomó el topos del conflicto de gatos y ratones mas no la variante de su inversión histórica, que la catástrofe del genocidio hizo impensable. Sin embargo, hubo seguramente otros dos factores que llevaron a nuestro cartoonist a adoptar el recurso de la animalización de la fábula. Nos referimos, en primer lugar, al uso de ese mismo procedimiento en las ilustraciones de manuscritos judíos de la Biblia y de sus comentarios en los siglos XIII y XIV, con el que, al parecer, se pretendía sortear la prohibición de la fabricación de imágenes del segundo mandamiento (se suponía que semejante veto alcanzaba sólo a las figuraciones humanas). (HOROWITZ, 2001, p. 665-684). En segundo lugar, es posible que el arte clásico de la psicofisonomía a la manera de Gianbattista Della Porta, que descubría afinidades de carácter psicológico entre animales y hombres a partir de sus semejanzas físicas, haya tenido también algún peso en la decisión tomada por Spiegelman. [Imagen 22] Las caras vulpinas, perrunas, bovinas, aquilinas de algunos hombres en particular cargaron de ambivalencias la animalización simbólica al ser extendidas a pueblos y colectividades enteras en el siglo XIX. (GALTON, 1883; GINZBURG, 2004). Maus ha evocado esa 
práctica de la cultura popular con ironía y hasta con paradójica ternura respecto de los judíosratones, según demuestra el episodio en el que los padres de Art se ponen caretas de cerdos y simulan ser polacos para salvarse de los nazis, pero Anja, la madre, no puede evitar que le salga el rabito de ratón por debajo del abrigo. (SPIEGELMAN, 1994, p. 136). Queda claro, por supuesto, que el empleo de la fábula ha llevado a una identificación máxima del mundo emocional entre hombres y animales. El sufrimiento de éstos es el sufrimiento de aquéllos y viceversa. [Imagen 23] La identificación se extiende y derrama en una suerte de arabesco (animal-hombre-animal) hasta alcanzar acentos paradójicos cuando el judío-ratón-hombre muere "extrañamente", "como aquel perro". (SPIEGELMAN, 1994, p. 82). [Imagen 24] Notemos que, en el animal metáfora del hombre, el punto más alto del dolor está asociado a una vista en escorzo, desde abajo, de las bocas de los ratones que lanzan un quejido o un grito. Tal vez sea lícito pensar que, detrás del estilema, se encuentre el antecedente remoto del gesto del Laocoonte como epítome clásico del padecer humano, trasladado por Spiegelman a la expresión animal. [Imagen 25] Podría pensarse también que el gesto extrapola la desesperación individual del Grito de Munch a una angustia colectiva radical.

No obstante, existen dos momentos del relato, el suicidio de Anja (SPIEGELMAN, 1994, p. 100-103) y el spleen de Art que acompaña al éxito de la primera parte de su libro, en los que la fábula de los animales se interrumpe para incluir dos episodios hechos con personajes humanos. En ambas ocasiones, la fórmula infernal ha pasado a dominar la representación. La primera vez, Spiegelman narra el suicidio de su madre en contrapunto con elementos psicoanalíticos que lo involucran, es decir, un hecho cercano al presente y más perturbador o acuciante para Artie, hasta ese momento, que las desventuras de ambos padres en el Lager. El título que lleva ese comic dentro del comic es: Prisionero en el Planeta Infierno. Una historia real. ${ }^{7}$ [Imagen 26] De modo que el entorno del presente es sentido por nuestro autor-protagonista como un báratro, totalmente humano. El desarrollo subsiguiente del relato del Holocausto en el pasado convertirá el tiempo del exterminio en un infierno más devastador aún que, además, explica e incluye el otro infierno, el de la culpa de Artie ante la muerte de Anja. Al comienzo del capítulo dos de la segunda parte, cuando un Art hombre, con máscara de ratón, está sentado frente a su tablero de dibujante y cuenta las circunstancias que rodearon la confección de la historieta y el éxito obtenido por la primera parte, hay moscas (insecto asociado al inframundo y al diablo) que vuelan alrededor de la cabeza de Art y luego, en dos cuadros seguidos, a los pies del artista y de los operadores de la televisión, se extiende una imagen de los cadáveres de ratones amontonados y enredados en las fosas de Auschwitz que podemos remitir a las fotografías del momento de la liberación del campo por los soviéticos y a los conjuntos apocalípticos de cierta cultura iconográfica europea y cristiana (Bosch; Bruegel; Rubens; los pintores y grabadores alemanes del siglo XVI). [Imagen 27]

El escenario infernal, explícito en el contenido narrativo de decenas de cuadros, encuentra un eco permanente y un refuerzo implícito en las formas quebradas que todo lo

\footnotetext{
${ }^{7}$ Véase el análisis iluminador de Dominick Lacapra (1998, p. 157-159).
} 
invaden, desde la tapa, con su hipertrofia de la cruz esvástica, pasando por la yuxtaposición de cuadros transversales, las redes ópticas de oblicuas que representan los marcos de cárceles y arquitecturas, hasta pequeños detalles en las figuras como el zigzag de las arrugas en la ropa. Por un lado, es probable que tales estructuras angulares resulten de un desarrollo plástico de la propia cruz gamada que domina títulos, paisajes e interiores, o bien de la "S" característica del logotipo nazi de la Schutzstaffel. Por otra parte, la forma dentada remite a una idea de quiebre, desestabilización y violencia, y podríamos considerarla entonces una construcción estética y un símbolo de la ruptura devastadora de la vida que el nazismo trajo consigo. Quizás una huella del empleo consciente de ese tipo de línea se encuentre en la firma del autor, en los rasgos de la " $\mathrm{t}$ " y la "s" de su nombre, que se modificaron a posteriori de tal suerte que ha desaparecido el ángulo agudo de la " $t$ ", mientras la " $s$ " se ha hecho más curvilínea y sinuosa. [Imágenes 28-29-30]

\section{In the Shadow of No Towers}

En 2004, bajo el efecto del terror provocado en su ánimo por el atentado del 11 de septiembre de 2001 contra las Torres Gemelas y las consecuencias políticas nefastas de largo alcance que desencadenó la guerra preventiva del presidente Bush, Art Spiegelman produjo un cartoon de gran formato, In the Shadow of No Towers, prodigio de inventiva y experimentación en el arte de las viñetas. (SPIEGELMAN, 2004). Obsérvese, por ejemplo, el quiebre de la frontalidad del cuadro que muestra más y más su espesor en la tercera dimensión hasta completar su mutación en la perspectiva de las Torres humeantes, cuyas sombras, existen todavía y se extienden a toda la página por debajo del resto de la viñeta. [Imagen 31] Muy pronto, en la gran página 2 del nuevo libro de historietas, el retrato naturalista de Artie cede el paso a su representación como aquel ratón de Maus que reasoma tenaz. Asistimos a su metamorfosis en cuatro cuadros en grisalla que flanquean al Art-ratón, dormido sobre su mesa de dibujo y amenazado por "Al-Qaeda y su propio gobierno" en partes iguales. [Imagen 32] El humo y el polvo del día del atentado reactivan en Spiegelman el recuerdo de su padre "cuando trataba de describir a qué olía el humo de Auschwitz" y vuelven a transformarlo en roedor. (SPIEGELMAN (2004, f.3). [Imagen 33] Pero no es el viejo animalito de Maus el único bruto que sufre, pues también lo hace el águila símbolo del imperio norteamericano atacado, que padece estrangulamiento en el acto de acompañar al pobre autor en los primeros instantes de pánico, (SPIEGELMAN, 2004, f.2) es degollada por Bush y Cheney, que la montan, mientras el ave se pregunta, entre desesperada y ridículamente cínica, “Por qué nos odian?” (SPIEGELMAN (2004, f. 4) [Imagen 34] Más adelante, en el pasaje "Armas de desplazamiento masivo", la angustia de Spiegelman se pone en acto mediante una sucesión de intercambios absurdos de las naturalezas humana y animal entre Artie y su gatito, hasta que Art se convierte nuevamente en el consabido ratón y lanza el gato por el aire con el siguiente "descargo": "Ninguna criatura salvo el artista ha recibido daños durante la creación de esta tira”.(SPIEGELMAN, 2004, f. 9) [Imagen 35] En el desarrollo de su historia 
personal a partir del 9-11, nuestro autor parodia a menudo comics del pasado pero, en la segunda parte del libro, traza una antología histórica del comic neoyorquino que le permite, a modo de compensación frente a tantas ansiedades y locuras trágicas del presente, evocar la alegría, propia y de los lectores de historietas a lo largo de todo el siglo XX, que ha suscitado ese arte merced a la felicidad y locuras cómicas de tiras como Kinder Kids, Happy Hooligan, Little Lady Lovekins and Old Man Muffaroo y Bringing up Father. Quizás para conjurar el infierno desatado por Bin Laden y Bush, la Mnemosyne de Spiegleman termina su recorrido en una apoteosis de la fraternidad y de la música que protagonizan los personajes de Crazy Cat. [Imagenes 36, 37]

\section{Waltz with Bashir: A Lebanon War Story}

Un caso singularísimo y muy reciente es el del film animado Vals con Bashir, obra de Ari Folman y David Polonsky, premiado en Cannes en 2008 y transformado en cómic en 2009. ${ }^{8}$ En septiembre de 1982, el Líbano estaba sumido al mismo tiempo en una guerra civil y en un enfrentamiento militar con Israel, cuyo ejército había llegado a controlar Beirut y custodiaba los accesos a la ciudad y los campos de refugiados palestinos en su interior, entre ellos Sabra y Chatila. El 15 de septiembre, tras el asesinato del presidente libanés electo, Bashir Gemayel, el ejército israelí logró rodear Sabra y Chatila, estableció puntos de observación en edificios elevados a su alrededor y restringió el ingreso y el egreso de los campos. Los líderes de Kataeb, el partido católico maronita de Gemayel, que controlaban también un importante cuerpo de milicianos, negociaron directamente con Ariel Sharon su ingreso a los campos con asistencia logística israelí. ${ }^{9}$ Entre el 16 y el 18 de septiembre de 1982, mil quinientos milicianos, comandados por Elie Hobeika, se dirigieron a Sabra y Chatila, adonde entraron a sangre y fuego. Cientos de civiles palestinos y libaneses de esas zonas presuntamente protegidas fueron masacrados: según las fuentes, las cifras varían entre cuatrocientos y tres mil quinientos hombres, mujeres y niños asesinados. $^{10}$

\footnotetext{
${ }^{8}$ La película mereció también una nominación al Oscar como mejor película extranjera y obtuvo el Globo de Oro en la misma categoría.

${ }^{9}$ En 1982, una comisión independiente, cuyo informe fue publicado al año siguiente, llegó a la conclusión de que el ejército israelí tuvo "participación directa o indirecta en la masacre". Macbride (1983, p. 191-192). La propia Comisión Kahan, del gobierno israelí, encontró que Israel era directamente responsible de la masacre y que el entonces ministro de Guerra Ariel Sharon lo era en forma personal, lo que causó su renuncia. Israel (1983)

${ }^{10}$ La Comisión Kahan estimó 460 muertos a partir de reportes de "la Cruz Roja libanesa, la Cruz Roja internacional, la Defensa Civil libanesa y los médicos del ejército libanés". La inteligencia del ejército israelí elevó la cifra a 700-800, número que la Comisión Kahan consideró que "posiblemente sea más ajustado a la realidad" y fue reiterado por la BBC: “Analysis: 'War crimes' on West Bank”, 17 de abril de 2002, http://news.bbc.co.uk/1/hi/world/middle_east/1935198.stm El periodista israelí Amnon Kapeliouk, de Le Monde diplomatique, sostuvo que tras la masacre la Cruz Roja debió disponer de dos mil cuerpos y que los falangistas se deshicieron de otros mil quinientos, lo que eleva el cálculo total a tres mil o tres mil quinientas víctimas. Kapeliouk (1982).
} 
Vals con Bashir narra el intento de su autor por recuperar sus memorias de la guerra de 1982, cuando era un soldado de infantería de tan solo 19 años, especialmente los recuerdos de su posible participación en la masacre de Sabra y Chatila. Esto transforma a la obra en un intento excepcional, por el que los participantes en el bando de los responsables de la masacre muestran sin ocultamientos el acto feroz que cometieron. Tanto la película como el cómic se inician con una serie de cuadros que son particularmente interesantes para nosotros. En lo que luego descubrimos es una pesadilla experimentada por otro veterano de la guerra del Líbano, Boaz Rein-Buskila, una jauría se lanza desenfrenada por las calles de una ciudad y arrasa todo a su paso, causando el terror de los paseantes. Veintiséis cimarrones se detienen ante el edificio donde vive Boaz, ladran, gruñen y aullan, amenazantes. Pronto nos enteramos de que una de las tareas desempeñadas por el atormentado coprotagonista durante la guerra había sido la de liquidar, en medio de la noche y a balazos, a los perros de las ciudades a medida que el ejército se aproximaba a ellas, pues se quería impedir que sus ladridos delataran la presencia de las tropas a los habitantes desprevenidos. Boaz mató 26 animales, el mismo número que los perros en la pesadilla. Las representaciones de brutos reflejan en este caso dos papeles diversos de los humanos en la guerra del Líbano. La ferocidad de los canes que se lanzan tras el personaje sedientos de venganza rememora la de los propios israelíes, responsables de las muertes de los cuzcos durante la invasión. Pero, a la vez, el sufrimiento de los animales, que reciben balas solamente por ladrar ante la presencia de extraños, nos remite inmediatamente a los tormentos experimentados por las inocentes víctimas civiles del conflicto. [Imágenes 38-39]

La metáfora de la desolación humana encarnada en la de las bestias reaparece una vez más en Vals con Bashir. En un momento, el personaje de Folman consulta a una psicóloga, quien le explica que la disociación es uno de los recursos humanos para enfrentar situaciones traumáticas que, de otro modo, se volverían insoportables. Como ejemplo, relata la historia de un soldado israelí, fotógrafo de profesión, quien había logrado soportar buena parte de la guerra tras convencerse a sí mismo de que veía los horrores de los que era testigo a través del objetivo de la cámara. Sin embargo, en un momento su artilugio colapsa, pues el joven soldado cobra conciencia del horror que se avecina cuando contempla los caballos árabes inútilmente despedazados en el hipódromo de Beirut. Los equinos habían sido masacrados por miembros de las milicias falangistas, aliadas de los israelíes, en su camino rumbo a Sabra y Chatila. La inocencia absoluta de la bestia tendida en el suelo, en cuyo ojo se refleja la silueta del soldado, prefigura una inocencia comparable en las víctimas de la inminente matanza de refugiados. [Imagen 40]

En ambos pasajes, el color es un elemento fundamental para la construcción del significado. Los perros y los hombres agresivos, tanto en el sueño cuanto en la memoria de lo realmente acontecido, están teñidos de un gris azulado y plomizo. El perro que es víctima de un disparo de Boaz tiene, por el contrario, un tono amarillo, procedente de la iluminación nocturna de la aldea, en contrapunto con un negro que lo enfría. Por otra parte, los caballos masacrados en el hipódromo exhiben un color marrón terroso y frío, que sólo se aclara en el reflejo sobre el ojo 
del bruto moribundo. [Imagen 41] El mismo tinte reaparece en los dibujos de las matanzas de seres humanos en Sabra y Chatila, se expande por decenas de cuadros y desenvuelve allí toda su gama, desde el ocre oscuro, semejante al de los caballos, hasta un amarillo dorado que, sin embargo, permanece frío. Incluso el fotograma que es el cuadro último de la historieta reproduce el cromatismo emocional que hemos descripto. Una luz amarillenta revela la desesperación de la mujer sobreviviente y testigo de la masacre. Las oposiciones formales también despuntan en la tensión entre vistas de lo alto y close ups, entre dibujo e imitación de la fotografía. La primera abarca el rango que va del climax de la visión aérea de los milicianos que ingresan a los campamentos, en las páginas 99 y 114, al acercamiento máximo del niño muerto luego de la masacre en la página 115 que espeja el close up del ojo del caballo en la página 65. [Imágenes 42-43] La segunda tensión se funda en una coexistencia de la figuración propia del cartoon y de un remedo de la fotografía intervenida, que progresa in crescendo en la larga secuencia de la matanza propiamente dicha hasta culminar en cinco fotogramas donde el arte del dibujante deja paso al testimonio de la cámara. En el film original, este mismo desarrollo se materializa en la oscilación entre dibujo animado y video. [Imagen 44]

Una combinación formal semejante de recursos estéticos aparece en la historieta de Rossell, Villar y Cossio, Rupay. En primer lugar, la fusión de dibujo, fotografía e imitación el grabado a modo de cita en el comic evoca una práctica similar en Vals con Bashir. Pero sobre todo, el despliegue del color en Rupay, aunque cargado de sentido como en la obra de Folman, resulta menos complejo. Además de los tonos de negro, gris y blanco, el único color presente es un rojo furioso y fuerte, que se aplica tanto a la bandera rojiblanca del Perú como a la enseña comunista y al constante derramamiento de sangre del que ambos bandos son responsables. [Imagen 45]

En el desarrollo precedente, hemos usado los términos representación y fórmula sin definirlos explícitamente. Nos referimos a "representación" en su doble significado: primero, la noción remite a un sentido material, esto es, los téxtos, imágenes y otros objetos culturales que, según Louis Marin, poseen una dimensión transitiva por la cual remiten a algo que está fuera de ellos, pero también tienen una dimensión reflexiva mediante la que apuntan a sí mismos. ${ }^{11}$ En segundo lugar, representación tiene un significado más general, es decir, un conjunto de prácticas culturales colectivas que son parte del universo social y contribuyen a darle forma, al tiempo que lo exponen o lo disfrazan. Así, la búsqueda acerca de las representaciones y sus apropiaciones indaga también sus orígenes sociales e incluye por lo tanto el análisis de las relaciones entre cultura y vida social material. ${ }^{12} \mathrm{Si}$ entendemos "representaciones" de esta

\footnotetext{
${ }^{11}$ En etal sentido, representar es, al mismo tiempo, dar presencia a un objeto o fenómeno ausente, que está fuera del acto de representación, pero también comparecer personalmente en la realización del acto de hacer presentes esos objetos. Significa presentar algo, pero también presentarse a sí mismo representando.

${ }^{12}$ A propósito del concepto de representación, véase Chartier (1996, 2006, p. 74-99).
} 
manera, es obvio que ellas pueden reforzar vínculos de dominación, pero también pueden socavarlos. En consecuencia, el estudi de las representaciones es al mismo tiempo el análisis de relaciones de fuerza sociales y políticas. (GINZBURG, 2000).

En el universo de representaciones correspondientes a un horizonte histórico determinado, es posible encontrar patrones a los que se retorna una y otra vez con el objetivo de elaborar las tensiones y conflictos en el seno de una sociedad. Podemos, por lo tanto, definir "fórmula de representación" como el conjunto de dispositivos culturales que se han constituido históricamente y que, al mismo tiempo, poseen una estabilidad relativa, de modo que son fácilmente reconocibles por el lector u observador. Sin embargo, también esas fórmulas están sujetas al cambio, en el sentido de que pueden ser modificadas para representar fenómenos nuevos o diferentes y ser vectores de significados nuevos, aunque en general éstos se relacionen con los antiguos. Precisamente, cuando los lazos entre hechos nuevos y fórmulas previas son difíciles de trazar o se vuelven problemáticos, quizás estemos ante los límites de la representación. (FRIEDLANDER, 2007).

Creemos haber mostrado que, en el caso de las masacres y genocidios, tema de nuestro programa de investigación desde hace años, el arte de las viñetas ha producido un ensanchamiento del significado de los relatos en palabras. Esa expansión se distingue y enriquece las dilataciones tradicionales del sentido ya cumplidas por las artes plásticas y el grabado desde los comienzos de la modernidad. La historieta anuda imágenes y escritura con una fuerza y una coherencia que son las más próximas a la energía inmediata de nuestras emociones en vida.

\section{Referências}

BURUCÚA, José Emilio. Cura Vitae y la representación del arca de Noé en el arte europeo de los siglos XVI y XVII. In: RUTA, Carlos (Ed.). Cura Vital: jornadas de filosofía medieval. San Martín: Unsamedita, 2011, en preparación.

BURUCÚA, José Emilio. Historia y ambivalencia. Buenos Aires: Biblos, 2006.

BURUCÚA, José Emilio. La imagen y la risa: las Pathosformeln de lo cómico en el grabado europeo de la modernidad temprana. Cáceres: Periférica, 2007.

BURUCÚA, José Emilio; KWIATKOWSKI, Nicolás. Hunt, Martyrdom, Hell: is it possible to forge a new global vocabulary regarding genocide based on a historical approach to the representation of massacres? Constellations. An International Journal of Critical and Democratic Theory, New York, v. 17, 2010.

CHARTIER, Roger. El mundo como representación: estudios sobre historia cultural. Barcelona: Gedisa, 1996.

CHARTIER, Roger. Escribir las prácticas: Foucault, De Certeau, Marin. Buenos Aires: Manantial, 2006.

CRUMB, Robert. The book of Genesis illustrated. Londres: W.W.Norton \& Co, 2009. 
DE VORAGINE, Jacques. La légende dorée. París: Garnier-Flammarion, 1967.

FRIEDLANDER, Saul (Comp.). En torno a los límites de la representación. Buenos Aires: UNQui, 2007. GALTON, Francis. Inquiries in human faculty and its development. Londres: Macmillan, 1883.

GINZBURG, Carlo. Family resemblances and family trees: two cognitive metaphors. Critical Inquiry, v. 30, n. 3, 2004.

GINZBURG, Carlo. Rapporti di forza: storia, retorica, prova. Milan: Feltrinelli, 2000.

HOROWITZ, Elliot. Existe-t-il un art juif? le peuple de l'image: les juifs et l'art. Annales, Histoire, Sciences Sociales, Paris, n. 3, p. 665-684, mayo/junio 2001.

HUMAN RIGHTS COUNCIL. Human rights in Palestine and other occupied Arab territories: report of the United Nations fact finding mission on the Gaza Conflict. 2009. Disponible en: $<$ http://www2.ohchr.org/english/bodies/hrcouncil/specialsession/9/

docs/UNFFMGC_Report.pdf $>$. Acceso en: mayo 2010.

ISRAEL. Ministry of Foreign Affaire. The Beirut massacre: the complete Kahan commission report. Princeton: Karz-Cohl, 1983.

KAPELIOUK, Amnon. Enquête sur un massacre: Sabra et Chatila. París: Seuil, 1982.

LaCAPRA, Dominick. History and Memory after Auschwitz. Londres: Cornell University Press, 1998. MACBRIDE, Seán. Israel in Lebanon: the report of international commission to enquire into reported violations of International Law by Israel during its invasion of the Lebanon. Londres: Ithaca Press, 1983.

OESTERHED, Héctor; SOLANO LÓPEZ, Francisco. El Eternauta. Buenos Aires: Record, 1998.

ROSSELL, Luis; VILLAR, Alfredo; COSSIO, Jesús. Rupay: historias gráficas de la violencia en el Perú. Lima: Contracultura, 2008.

SACCO, Joe. Palestine. Nueva York: Fantagraphics Books, 2007.

SACCO, Joe. Safe Area Gorazde: the war in eastern Bosnia 1992-95. Nueva York: Fantagraphic Books, 2000.

SANDARS, Nancy. K. (Ed.). The epic of Gilgamesh. Nueva York: Harmondsworth, 1977.

SHAKESPEARE, William. Como gustéis: acto II, escena 1. In: _. _ _ _. Obras completas. Madrid: Aguilar, 1951.

SPIEGELMAN, Art. In the shadow of no towers. Toronto: Pantheon Books, 2004.

SPIEGELMAN, Art. Maus: Historia de un sobreviviente. Buenos Aires: Emecé, 1994.

VÁZQUEZ, Laura. El oficio de las viñetas. Buenos Aires: Paidos, 2010.

VIGNY, Alfred de. La mort du loup. In: . Les destinées. Editora: Local, 1864. 


\section{Imágenes}

1. Leona herida, siglo VI a. de C.

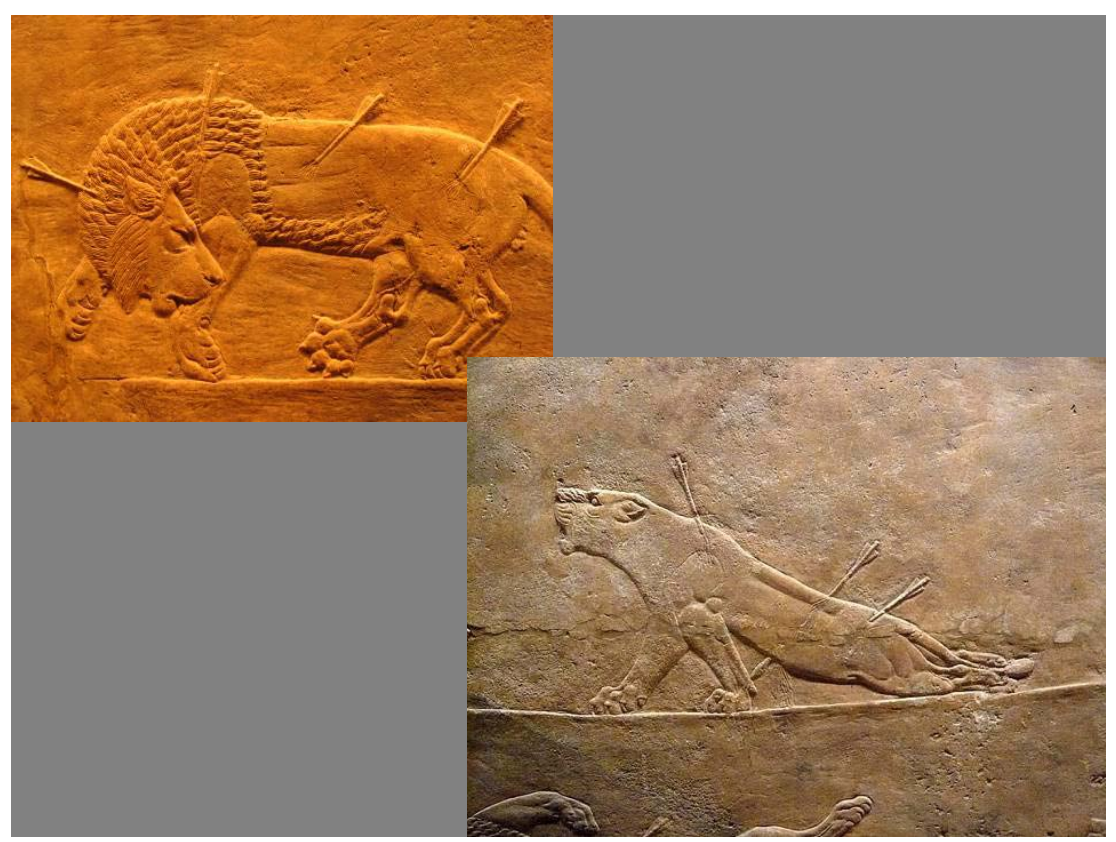

2. Pisanello (1450) y Durero (1502), La visión de San Eustaquio.

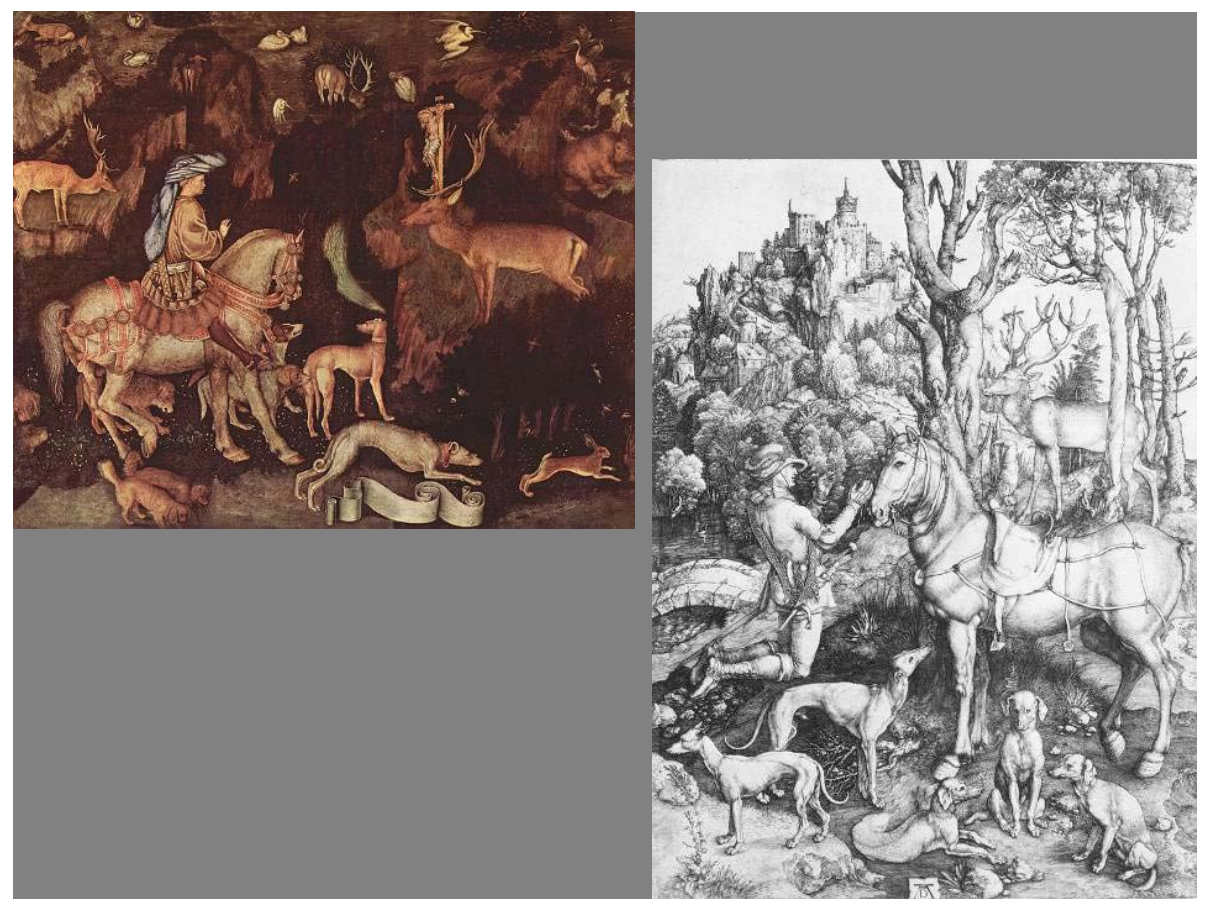


3. Sinagoga de Hodorov, Ucrania, 1714.

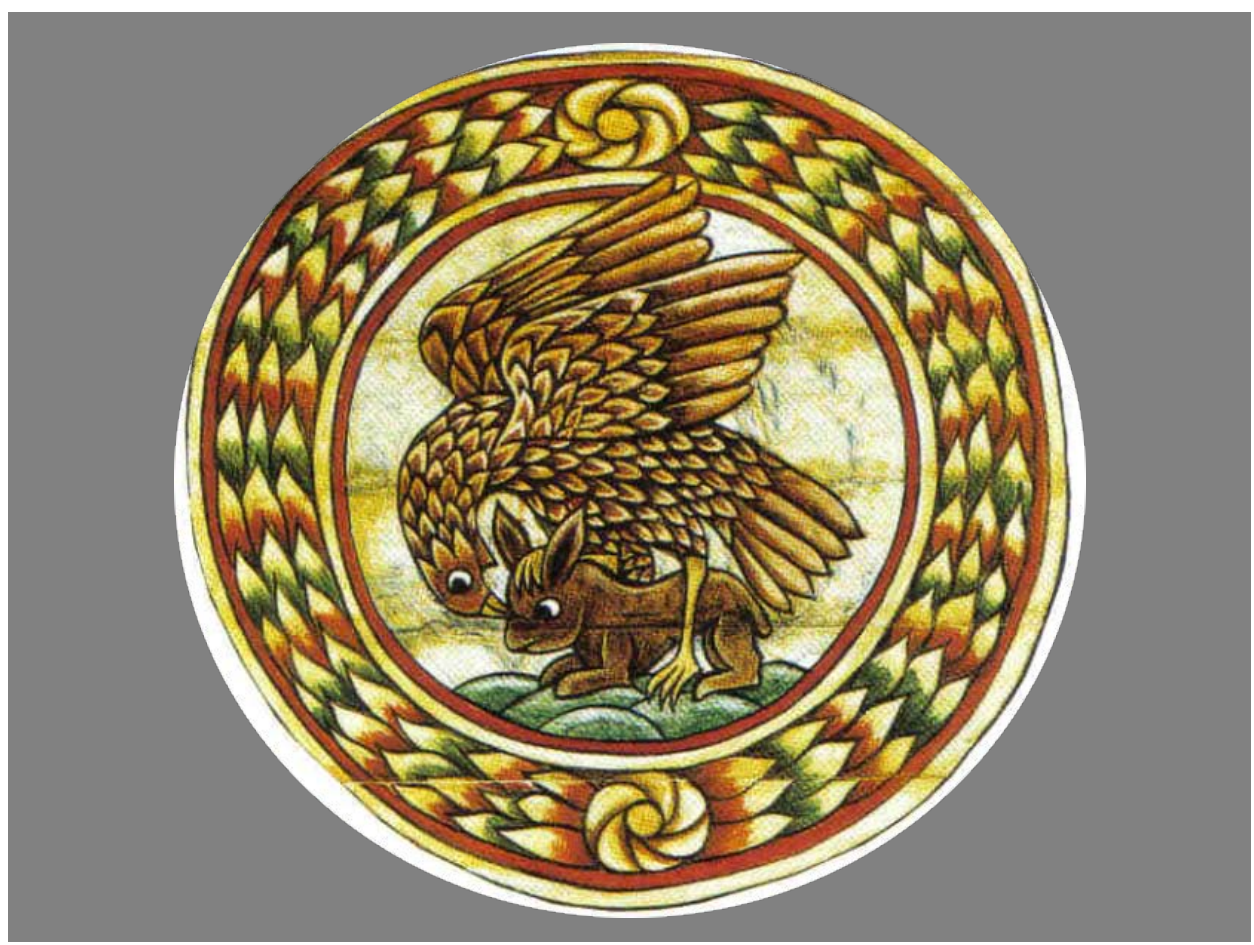

4. My Winnipeg.

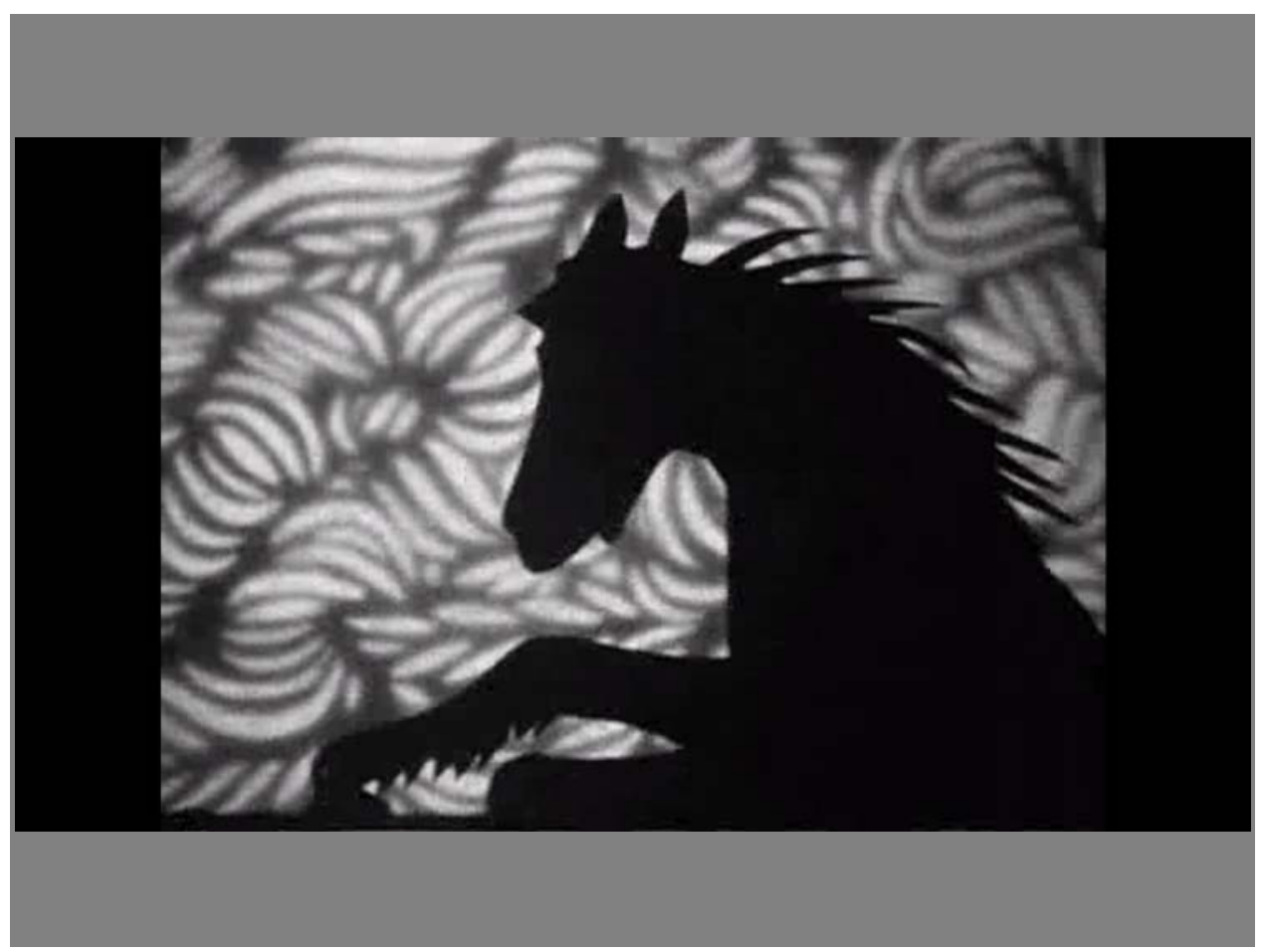


5. R. Crumb, Book of Genesis, 2009, diluvio.

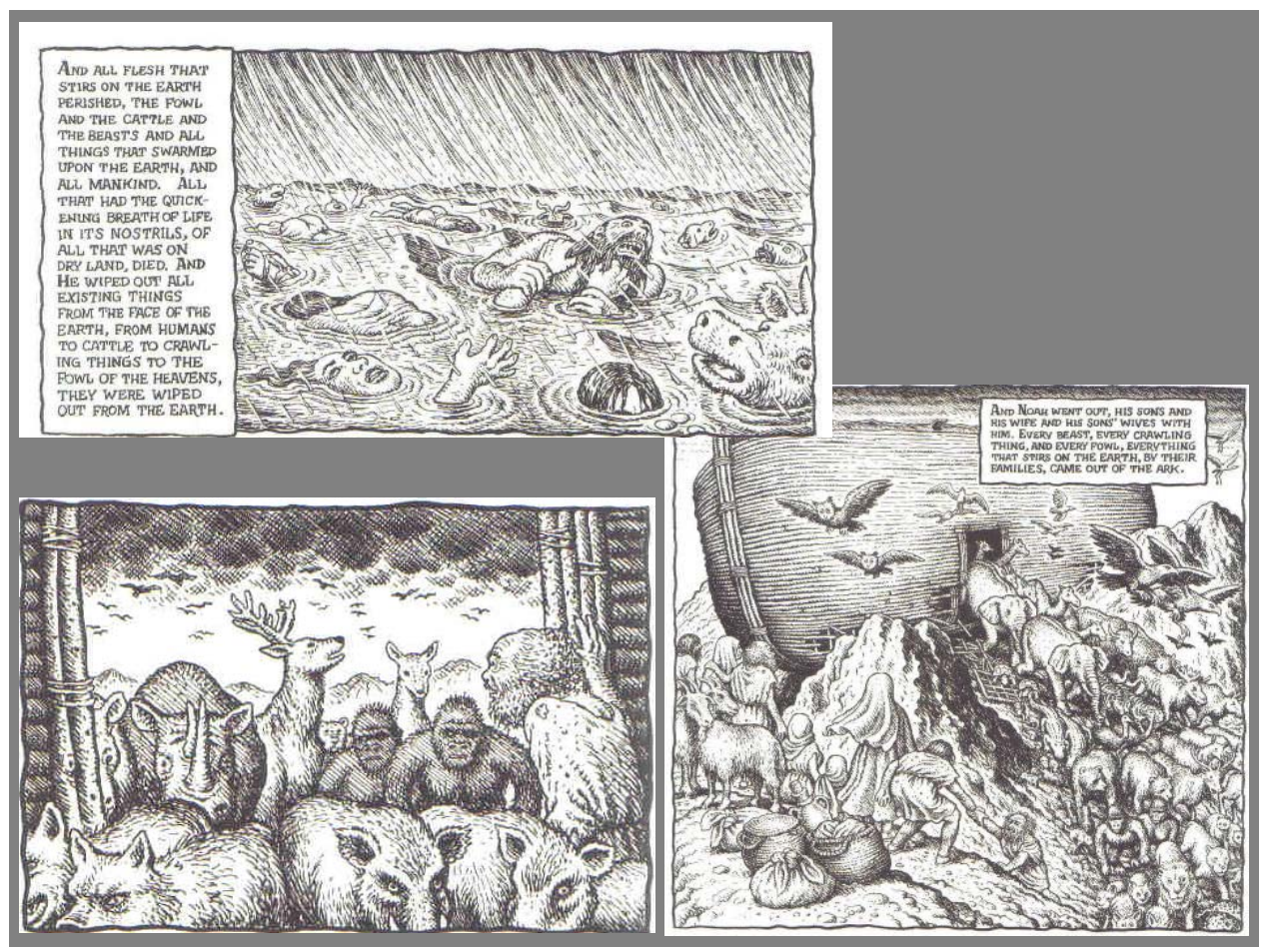

6. R. Crumb, Book of Genesis, 2009, Dios malo.

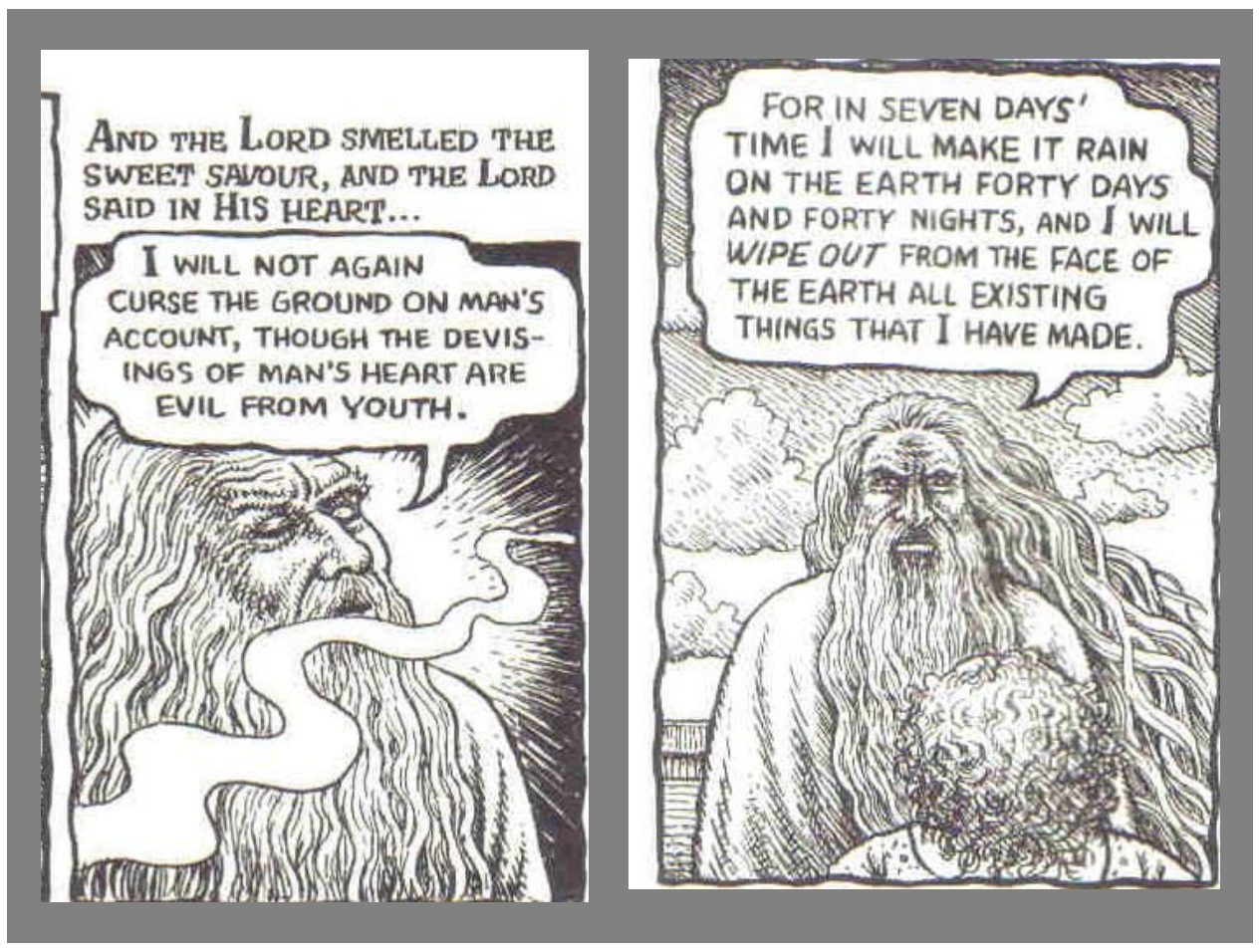


7. Oesterheld y Solano López, El Eternauta, 1958, Polsky y caballo muertos.

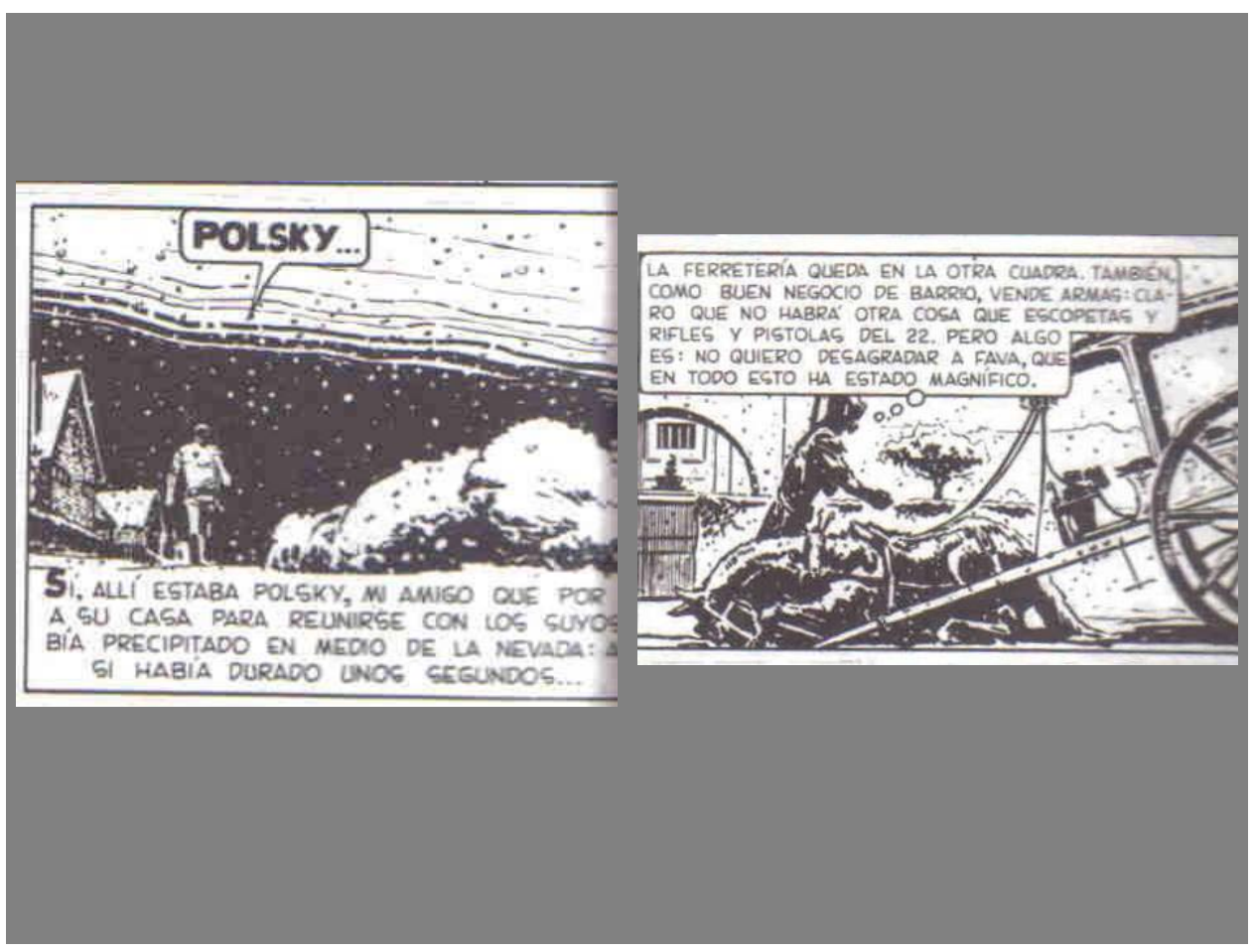

8. Oesterheld y Solano López, El Eternauta, 1958, pollitos.

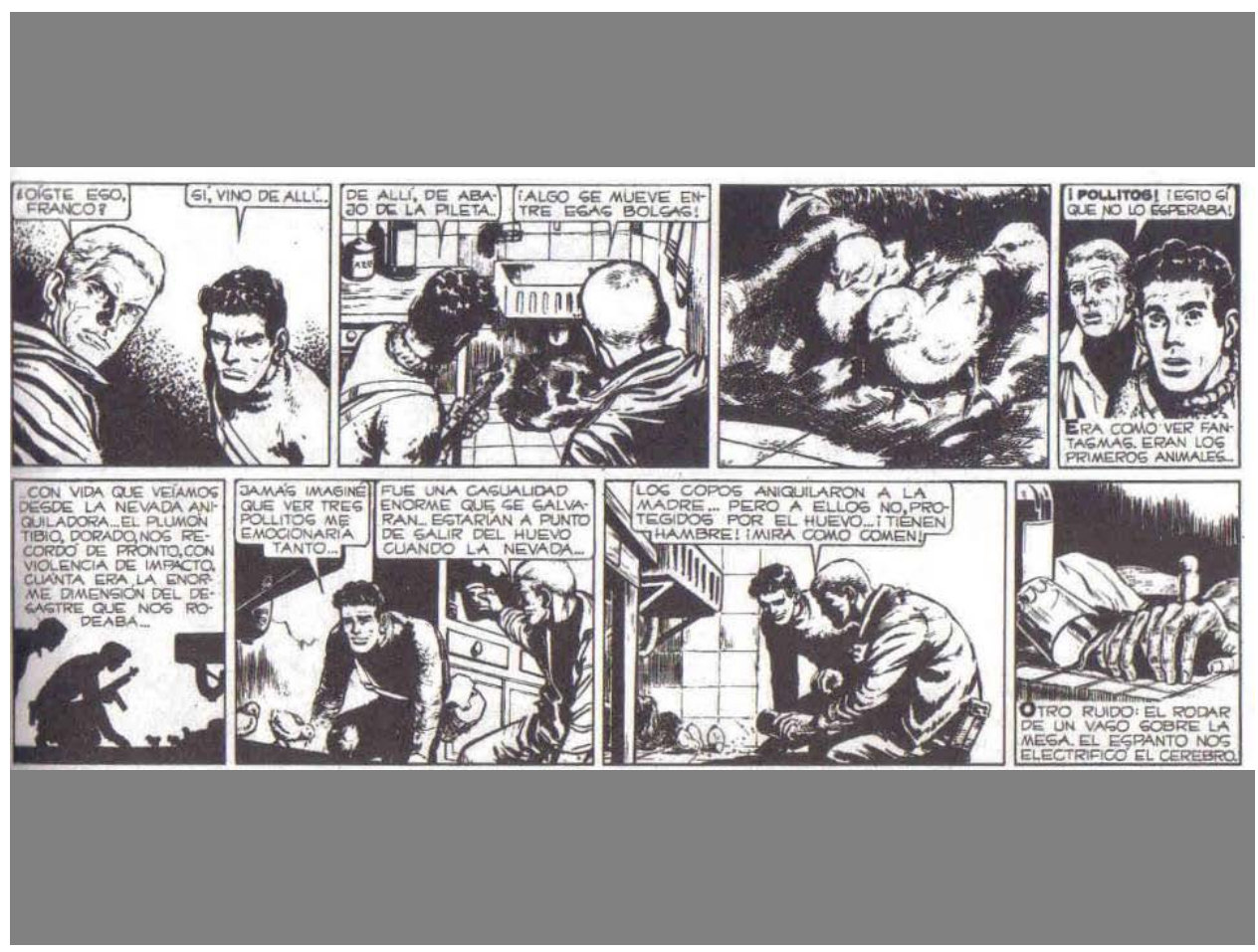


9. Oesterheld y Solano López, El Eternauta, 1958, mano muere.

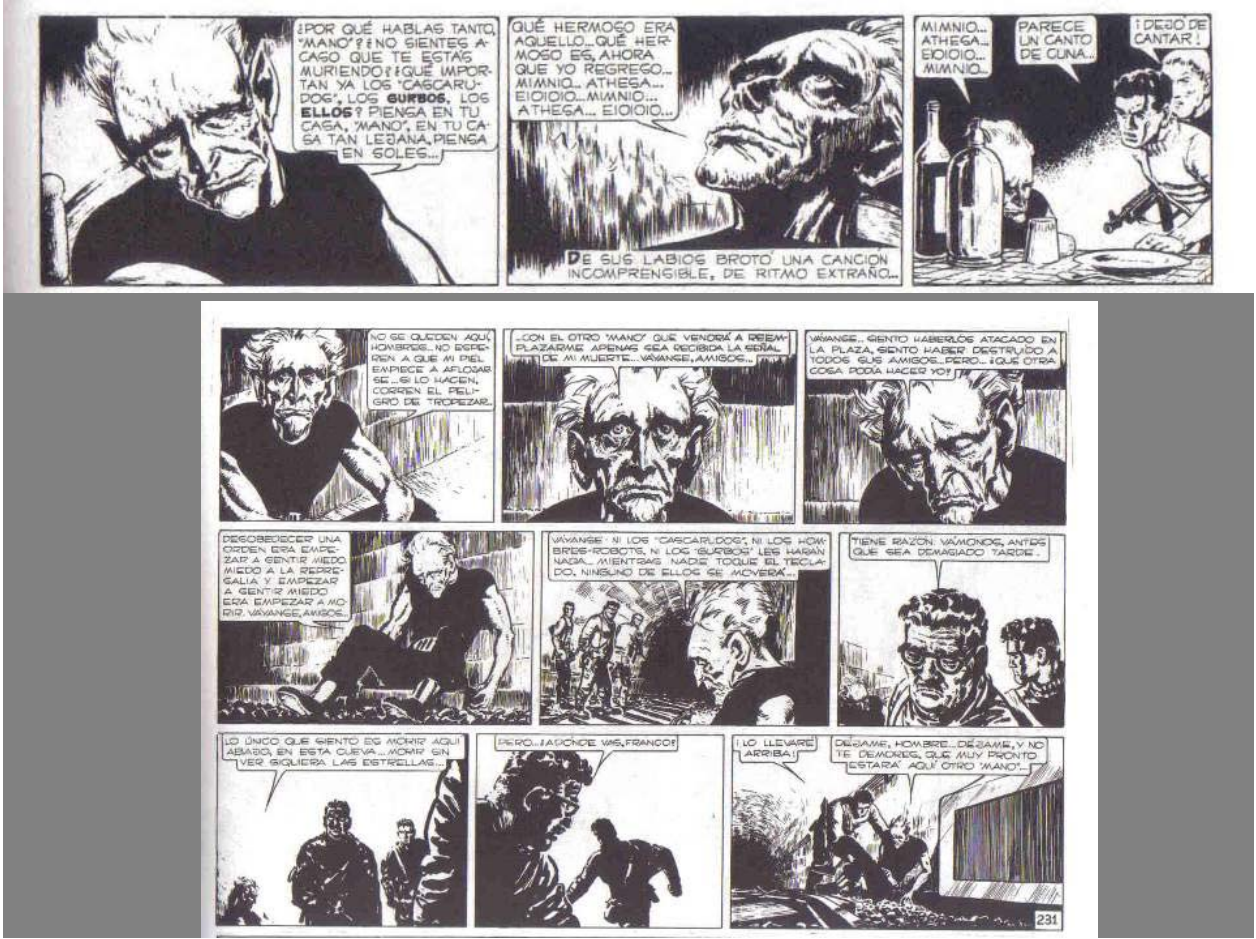

10. Joe Sacco, Safe Area Gorazde, 2000, visiones infernales.

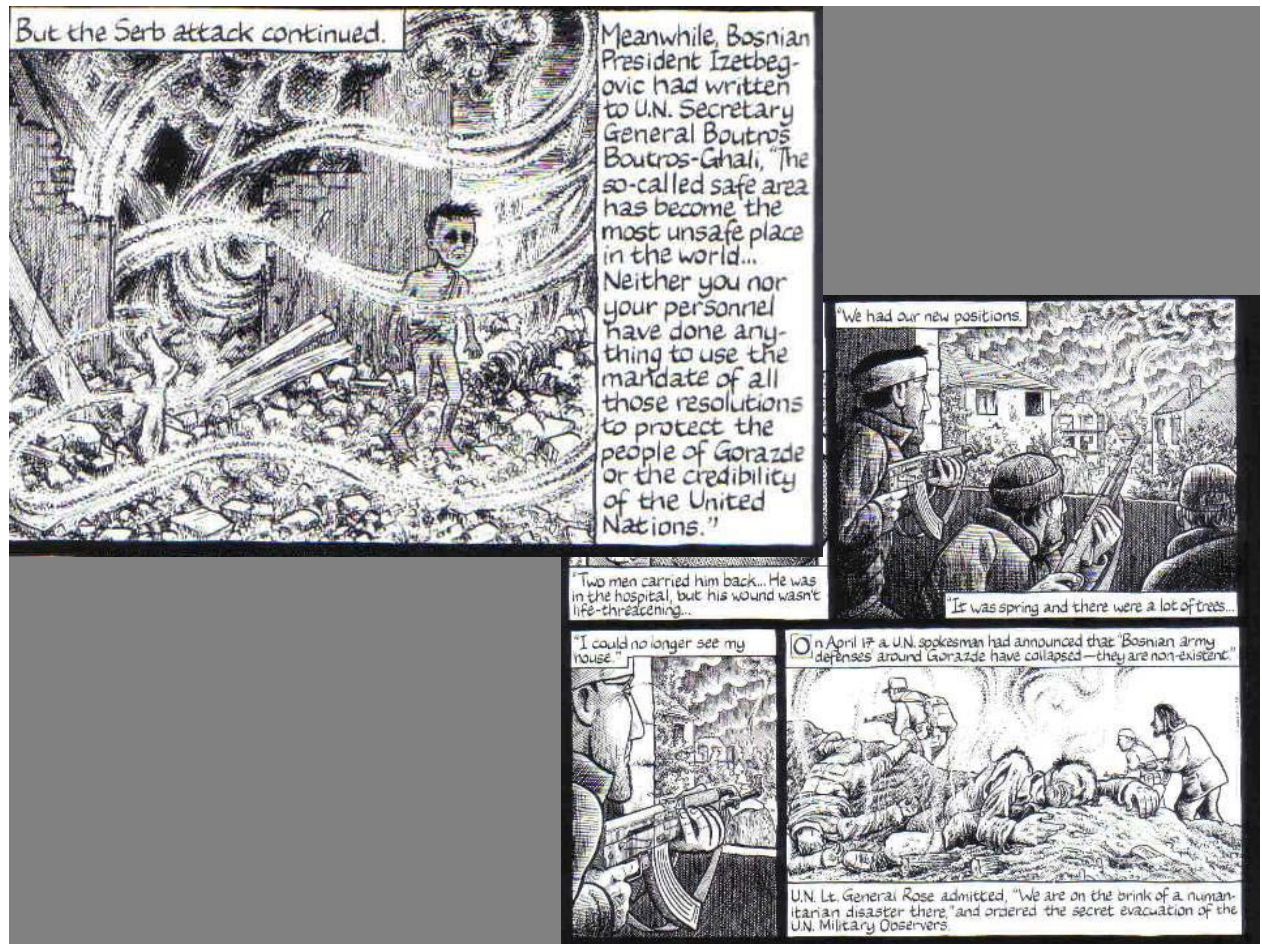


11. Joe Sacco, Safe Area Gorazde, 2000, martirio, y John Foxe, Book of Martyrs, 1586.

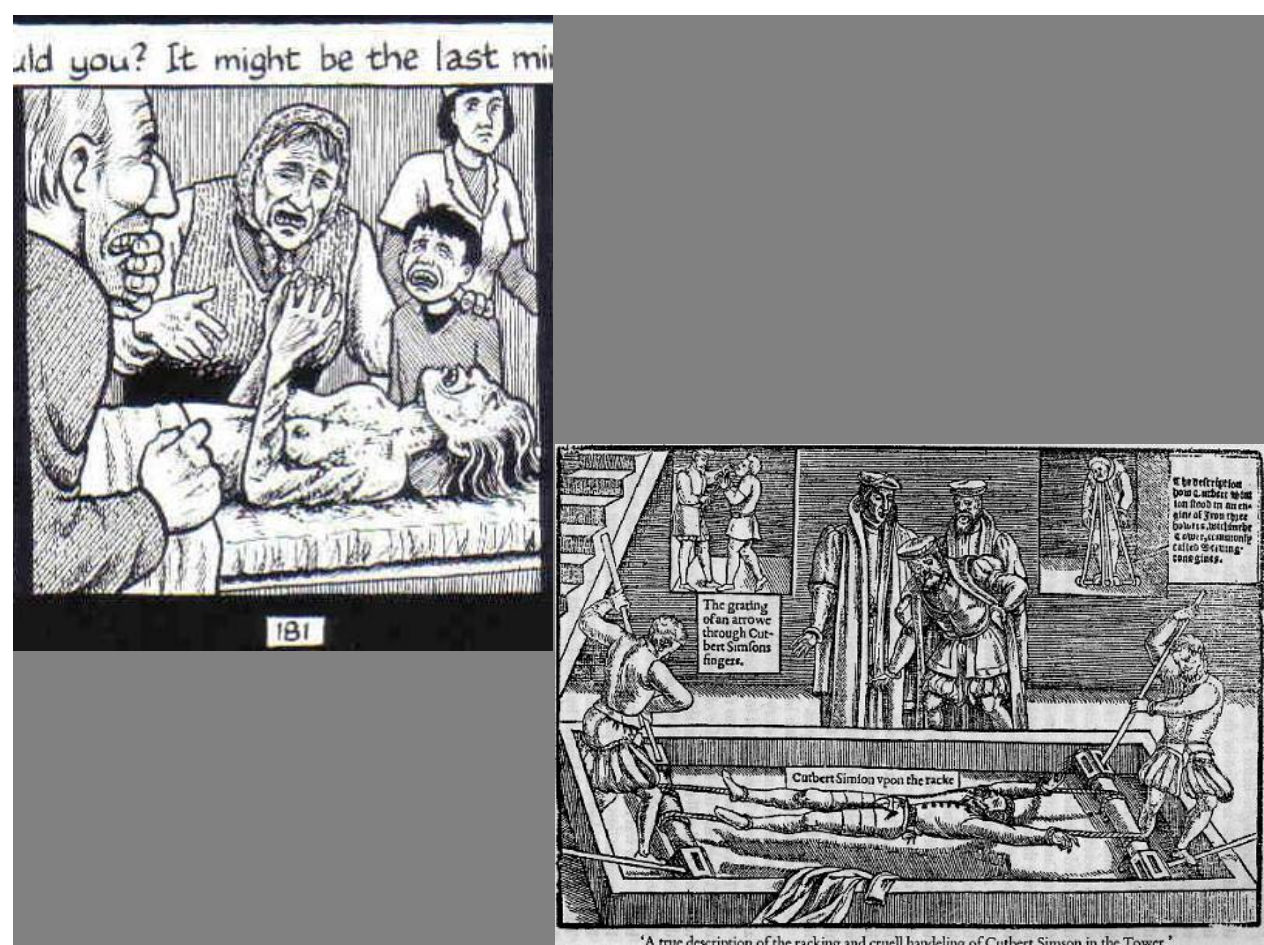

12. Joe Sacco, Safe Area Gorazde, 2000, fosa común.

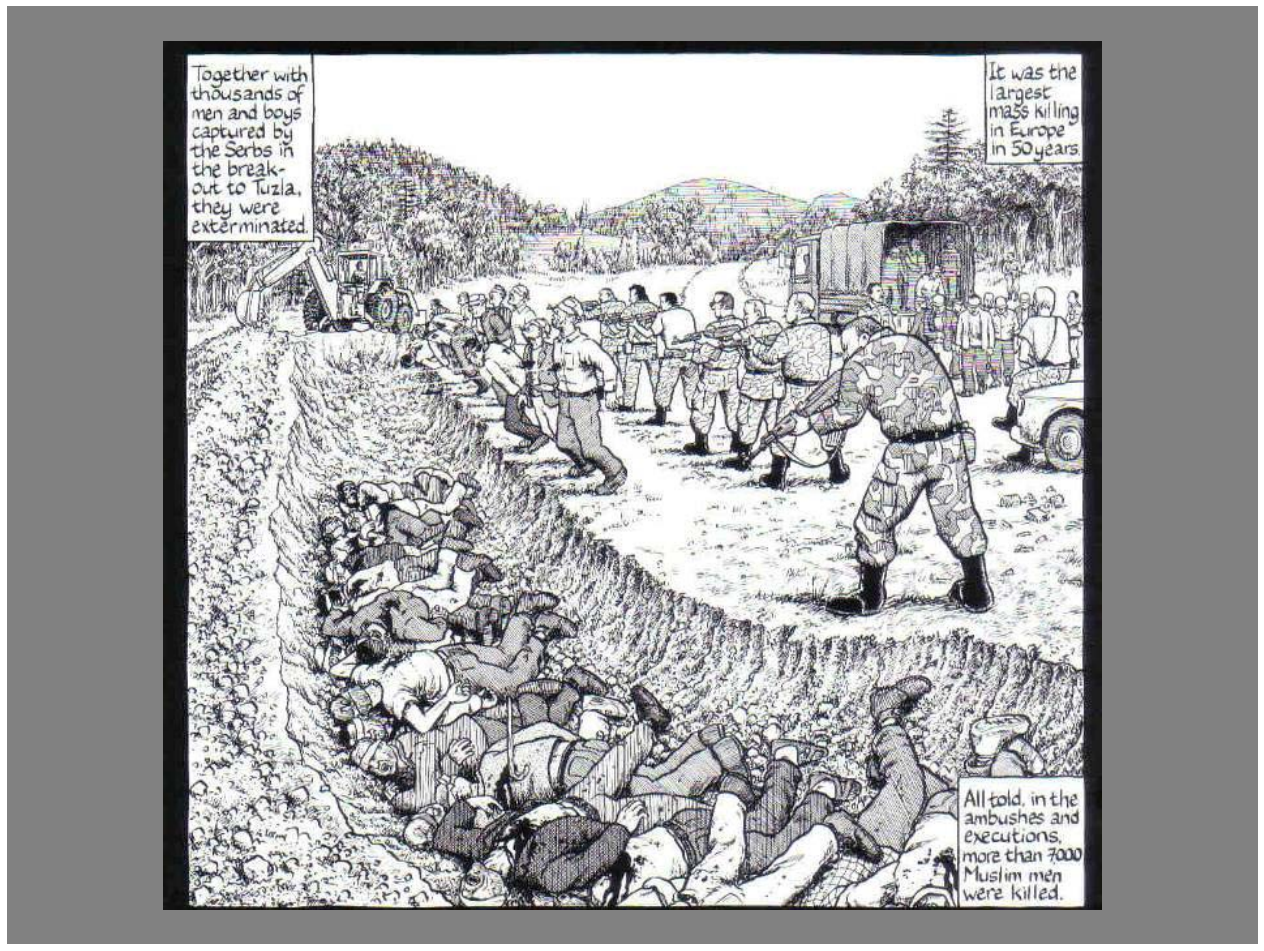


13. Joe Sacco, Safe Area Gorazde, 2000, exilios de hombres y animales.

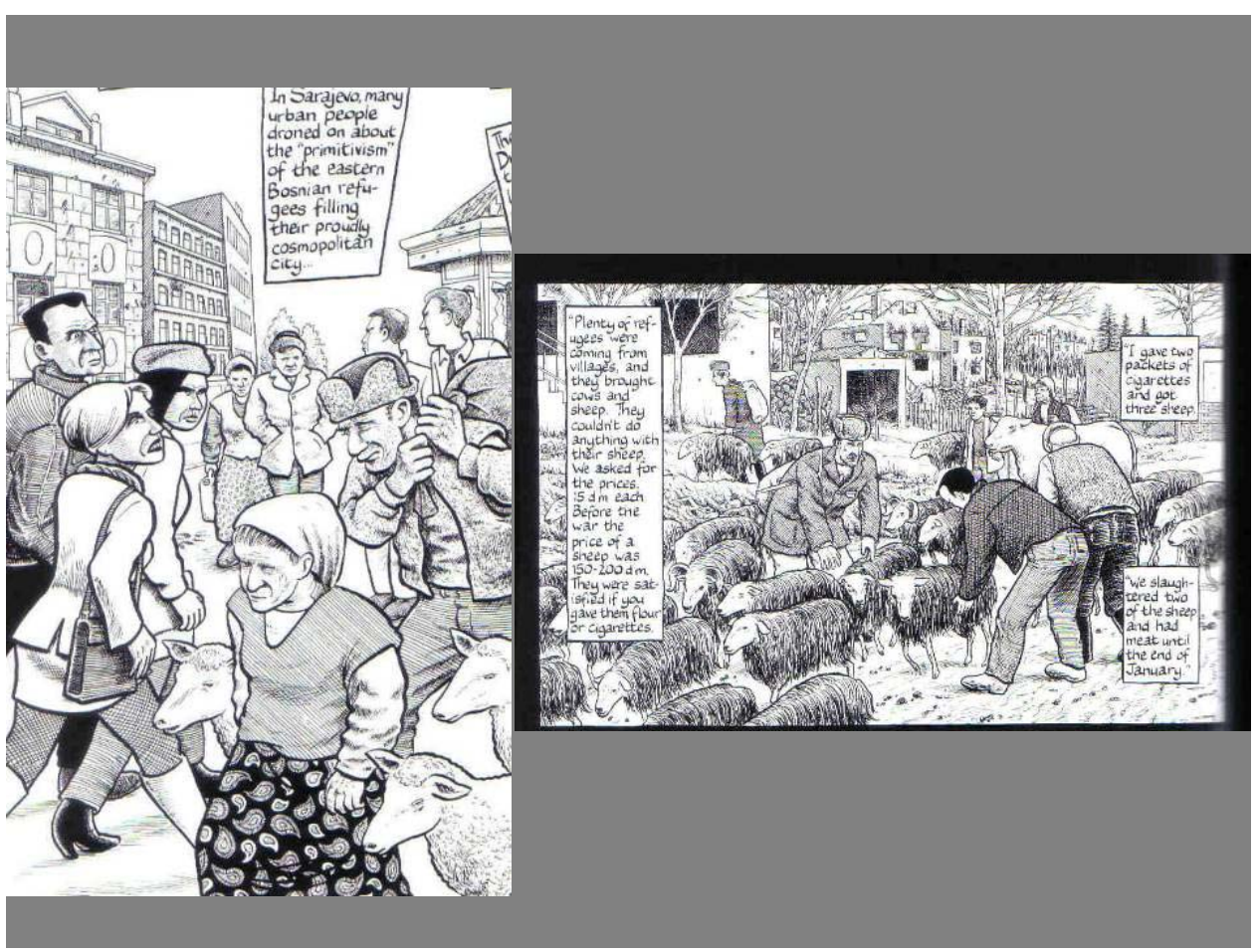

14. Joe Sacco, Palestine, 2001, ira.

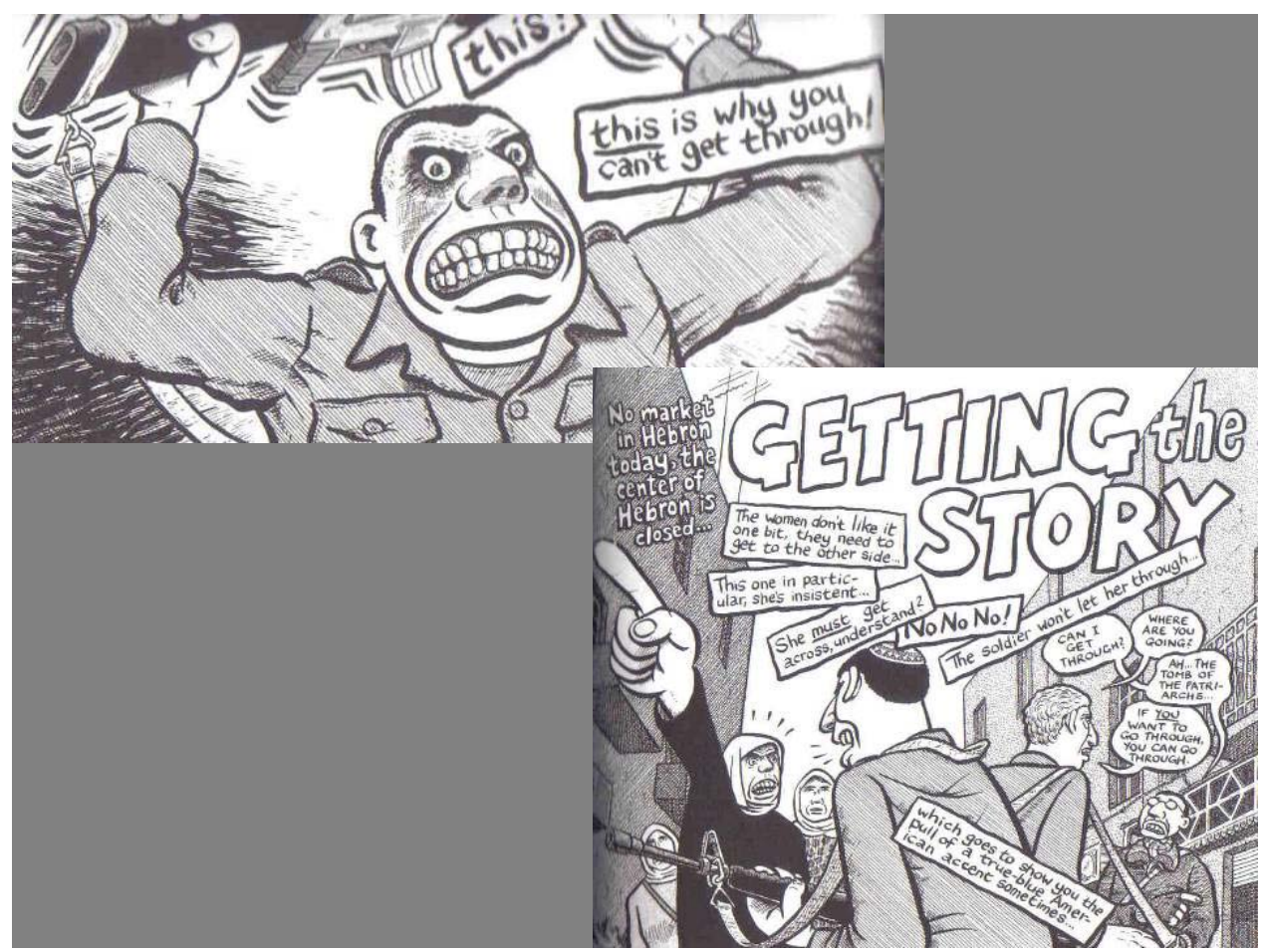


15. Joe Sacco, Palestine, 2001, chiste.

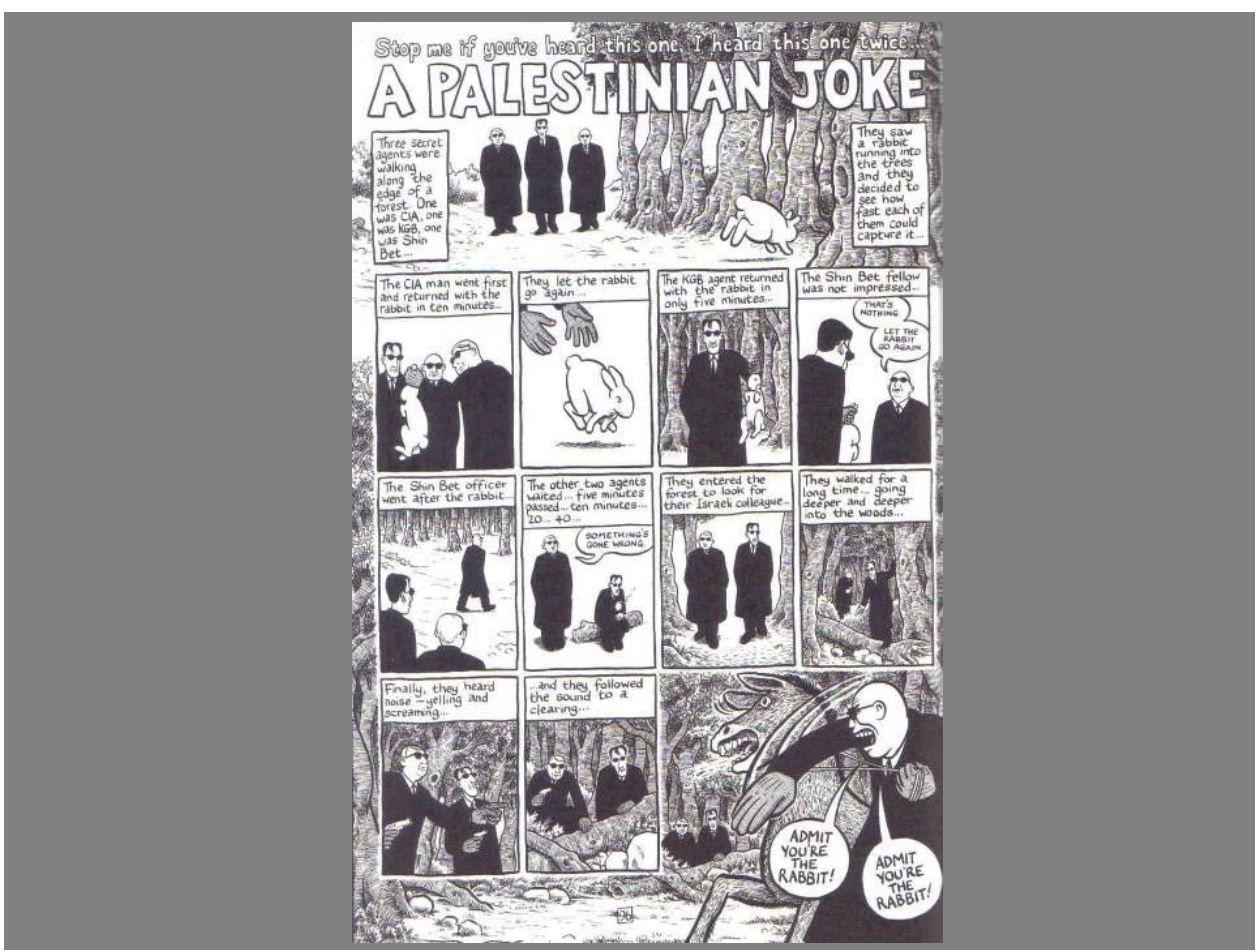

16. Joe Sacco, Palestine, 2001, sufrimiento femenino.

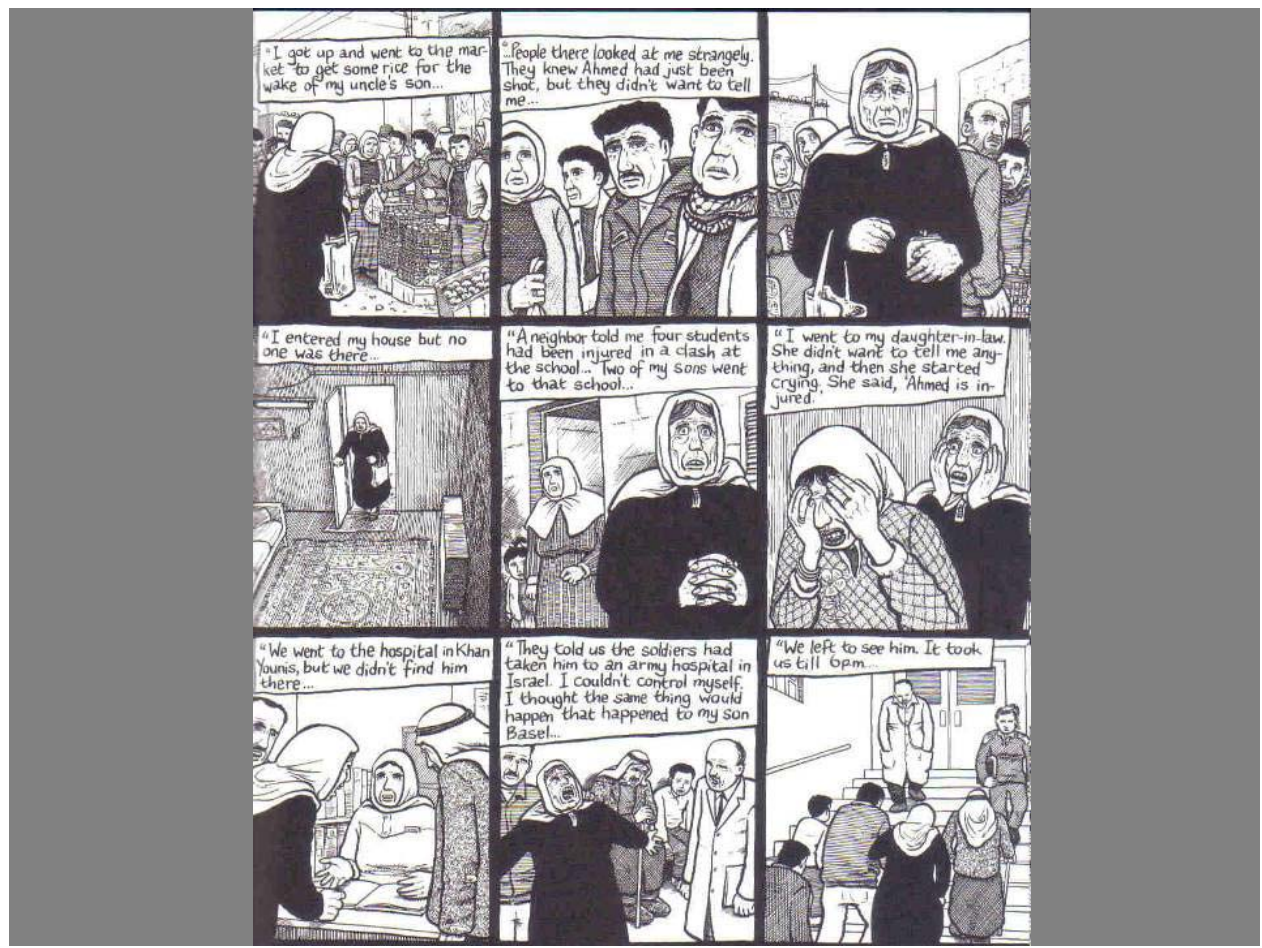


17. Joe Sacco, Palestine, 2001, tortura, close up, cenital.

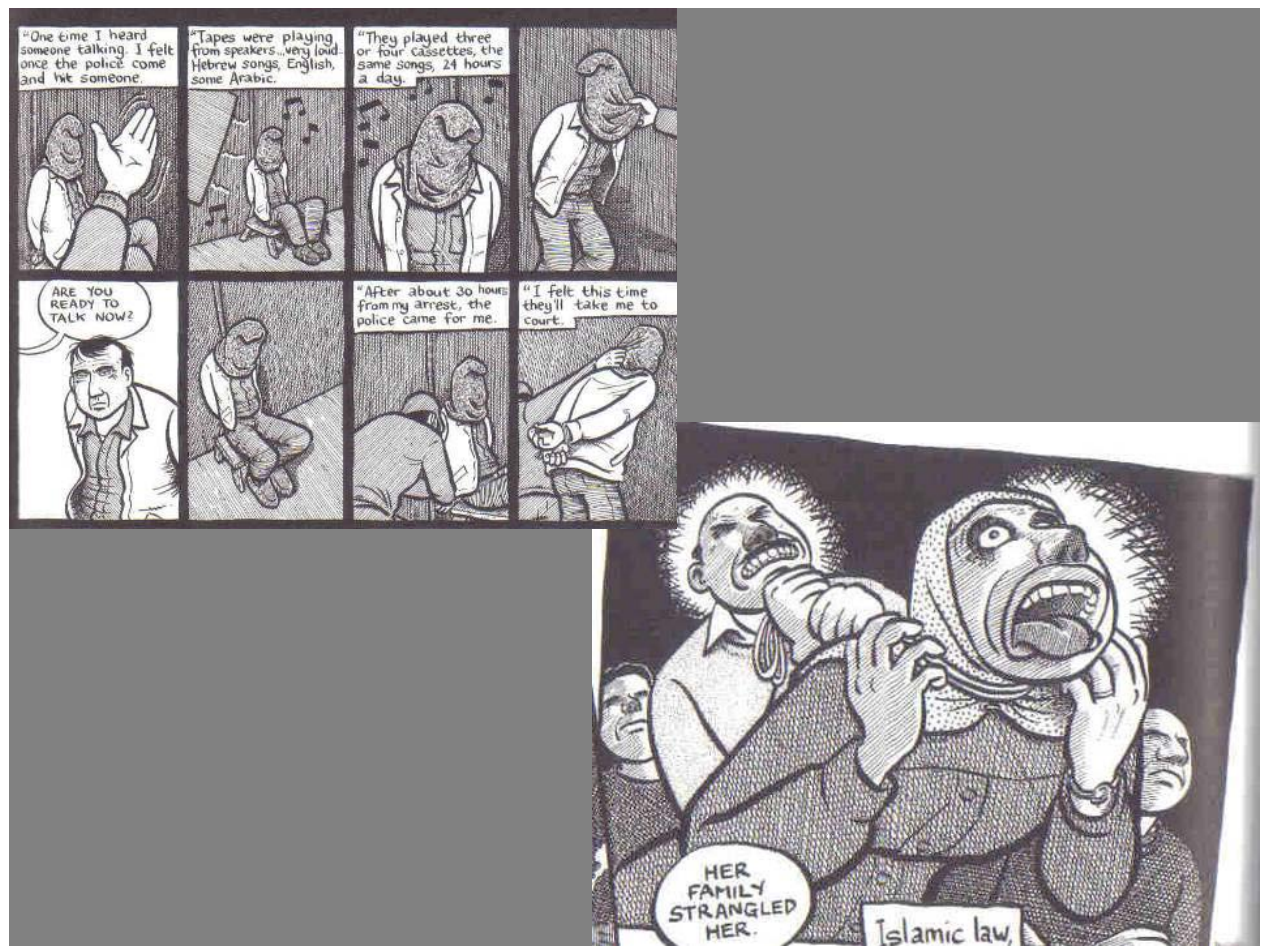

18. Joe Sacco, Palestine, 2001, idem.

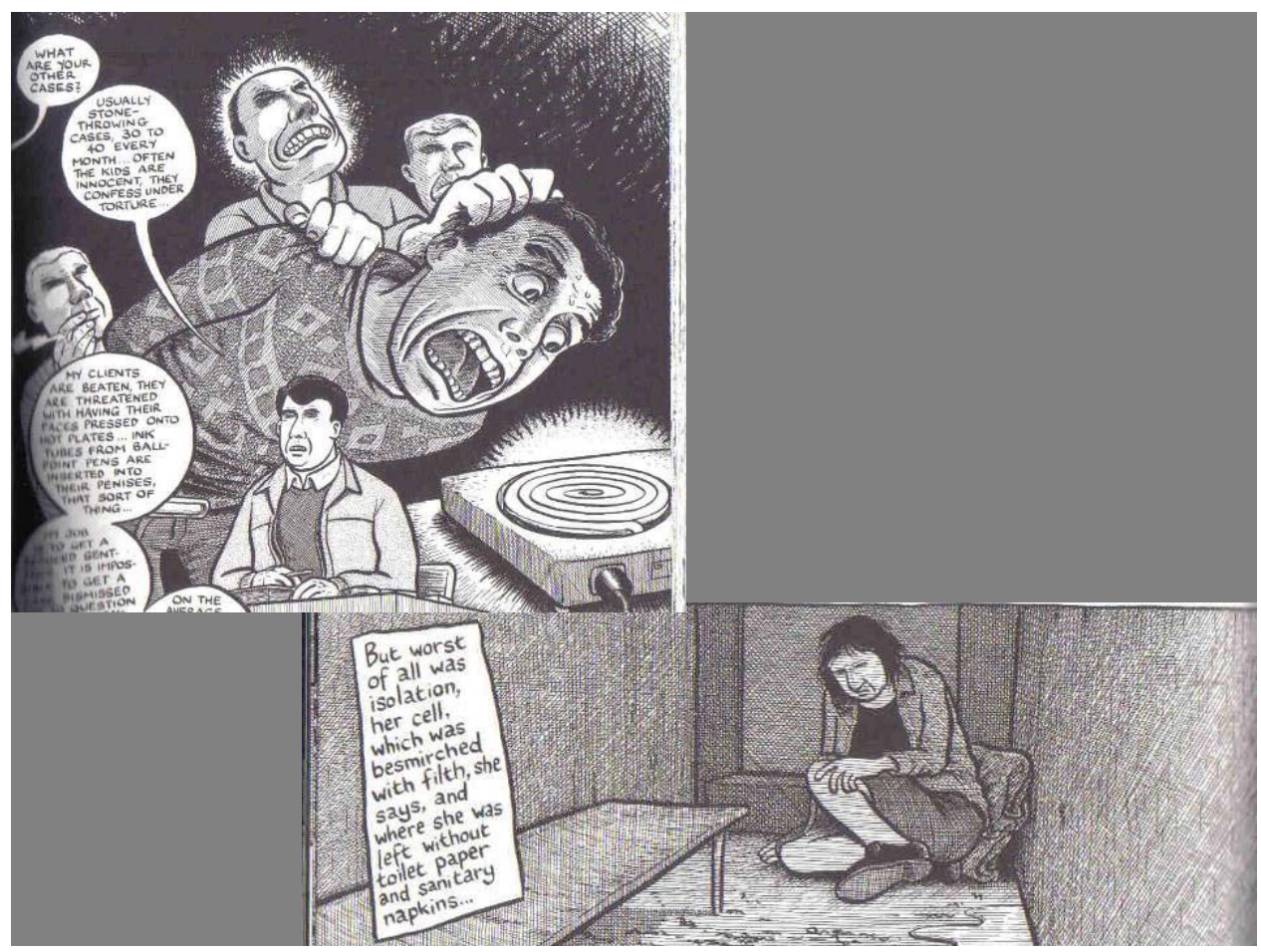


19. Joe Sacco, Palestine, 2001, multitud sufriente.

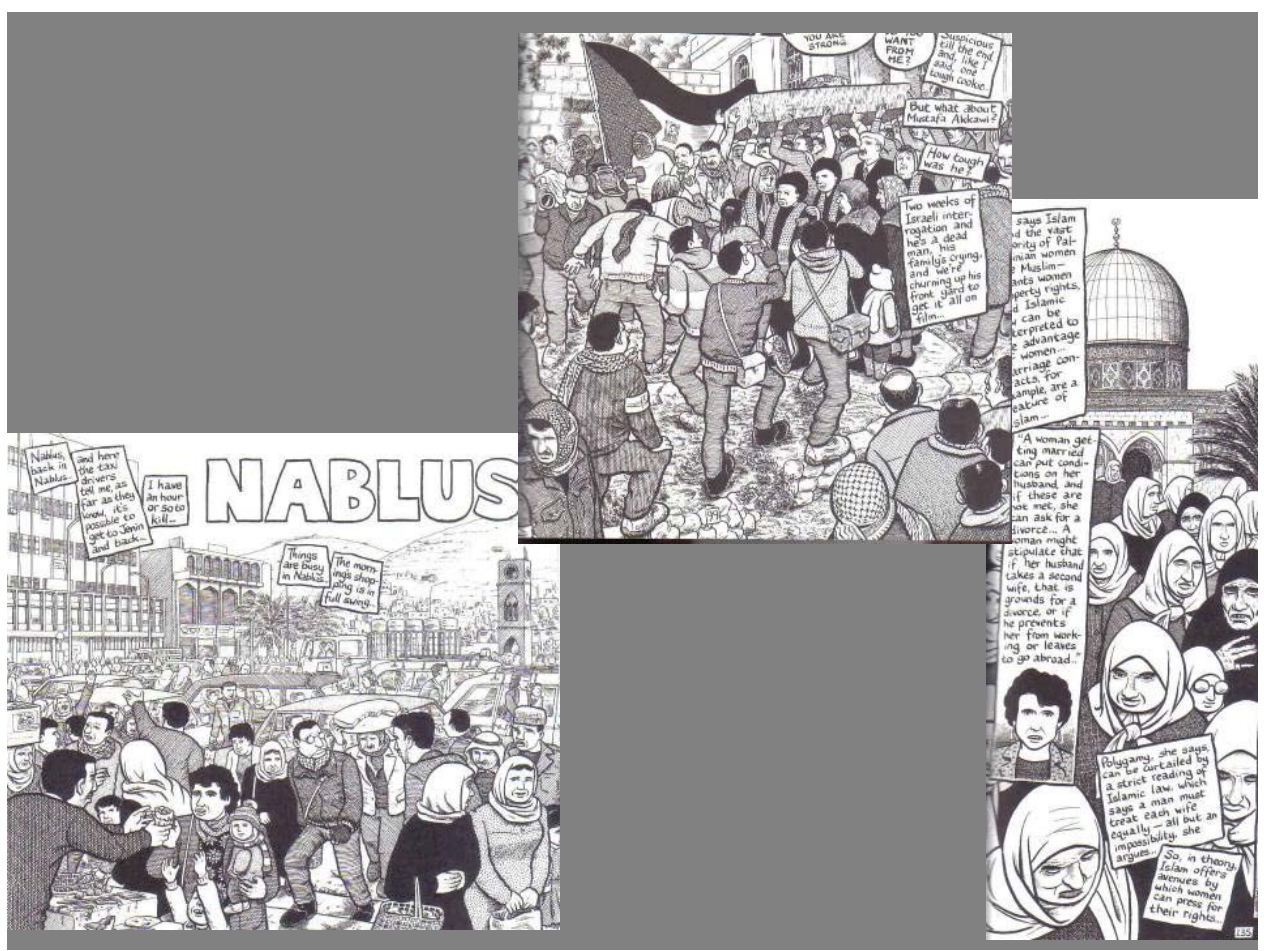

20. Luis Rossell, Alfredo Villar y Jesús Cossio, Rupay, 57-58.

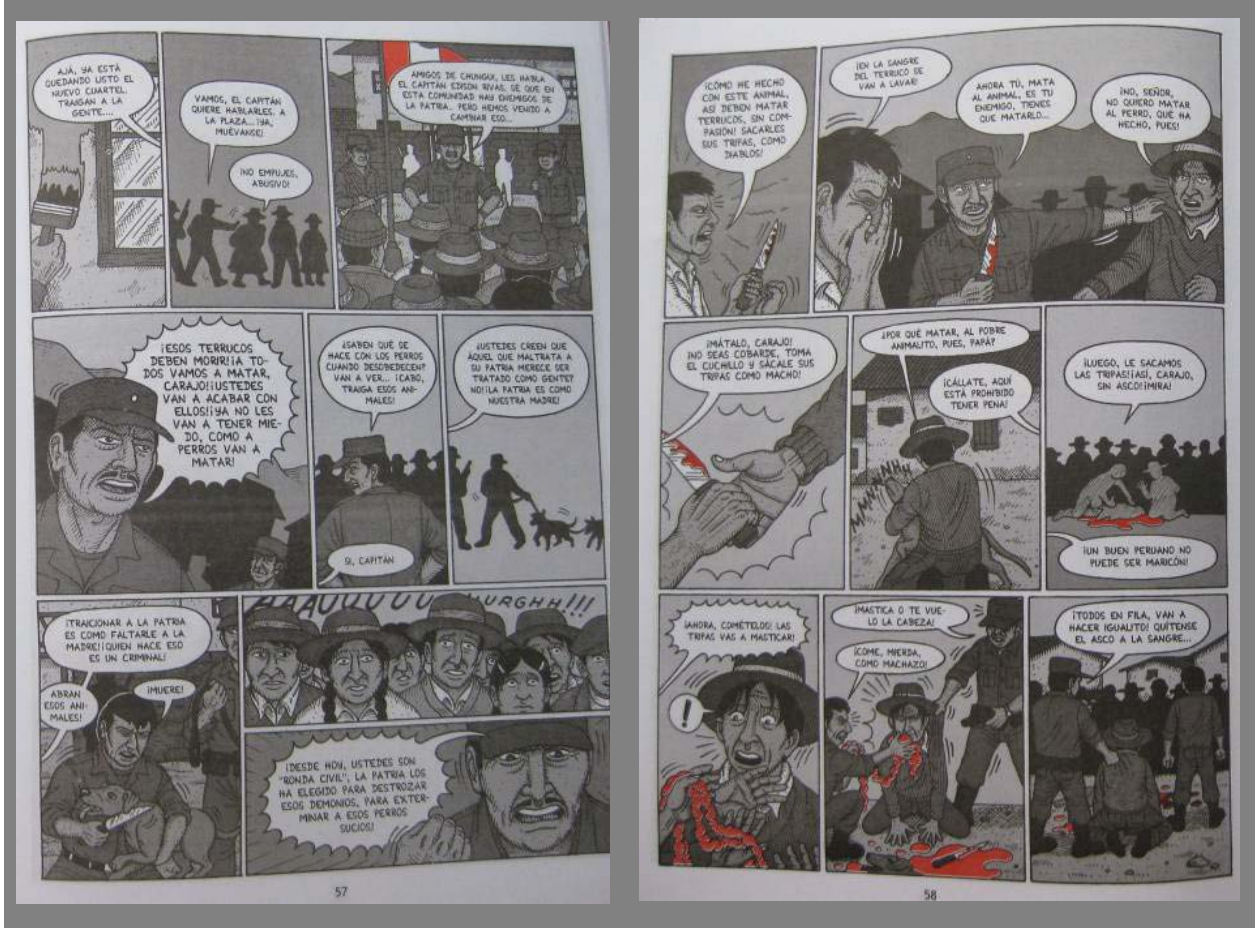


21. Grabados de animales, guerra de los Treinta Años, Callot.

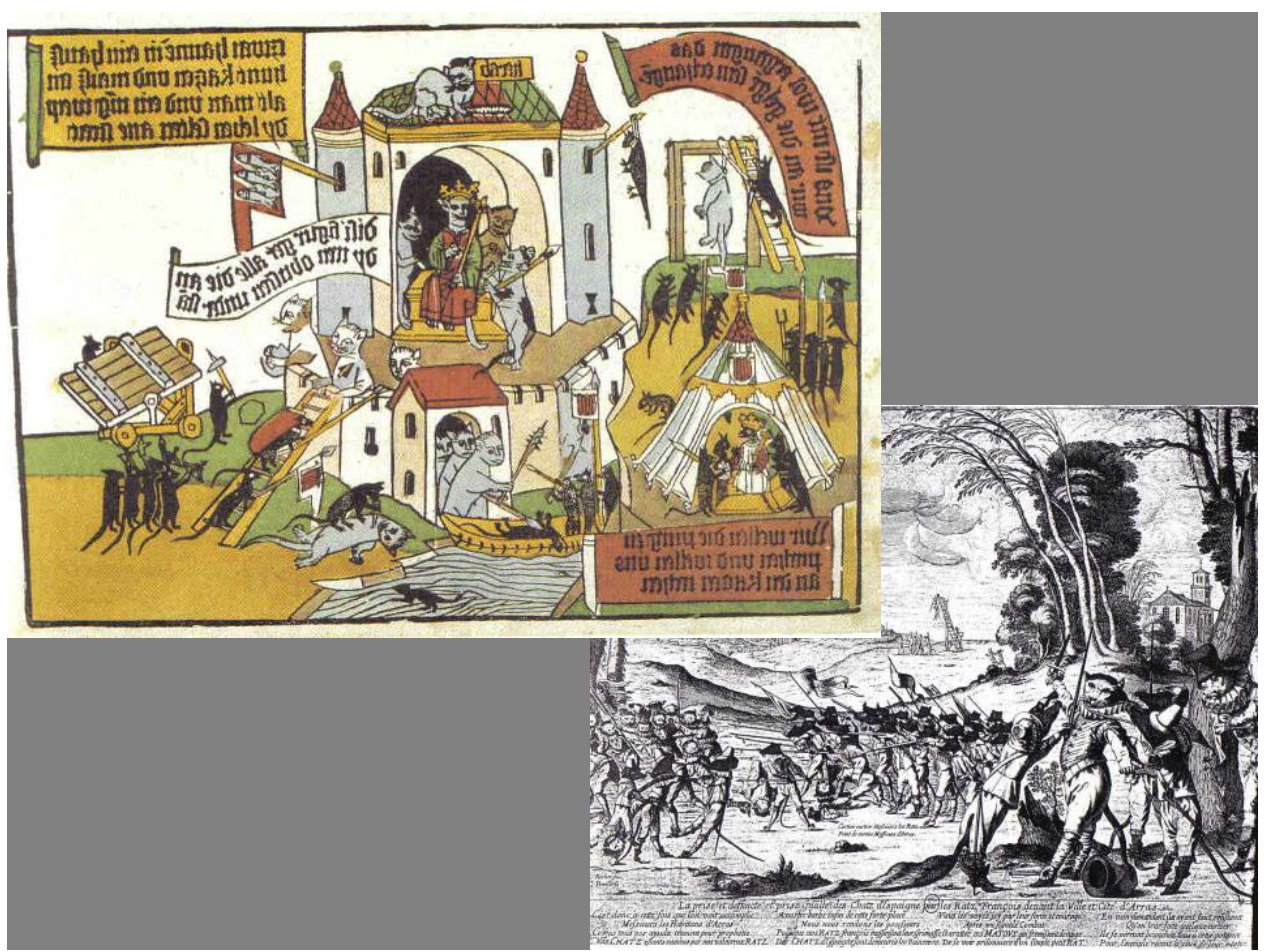

22. Della Porta, De humana physiognomia, 1586.

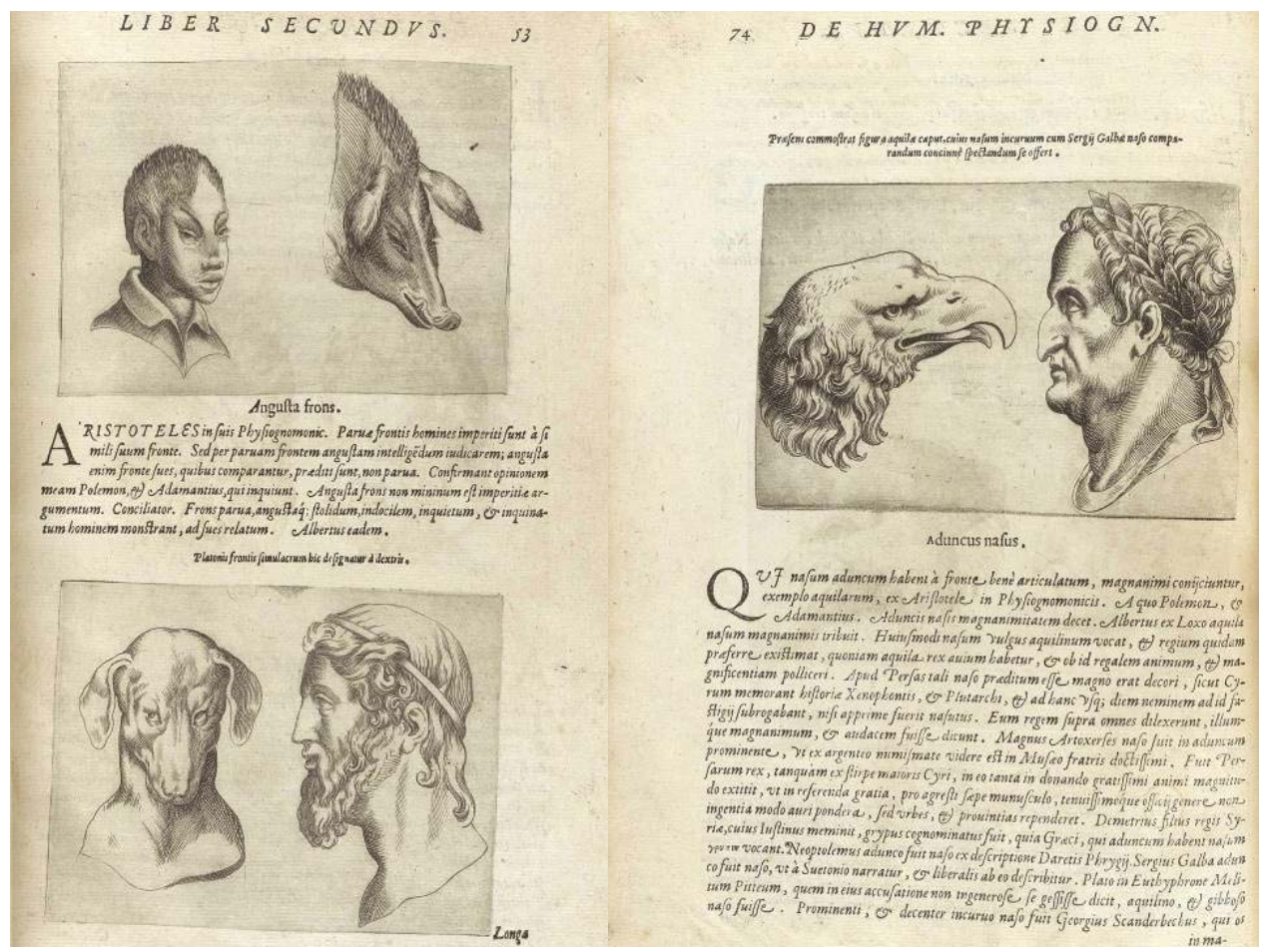


23. A. Spiegelman, Maus, 1973-1986, uso de la fábula en Maus.
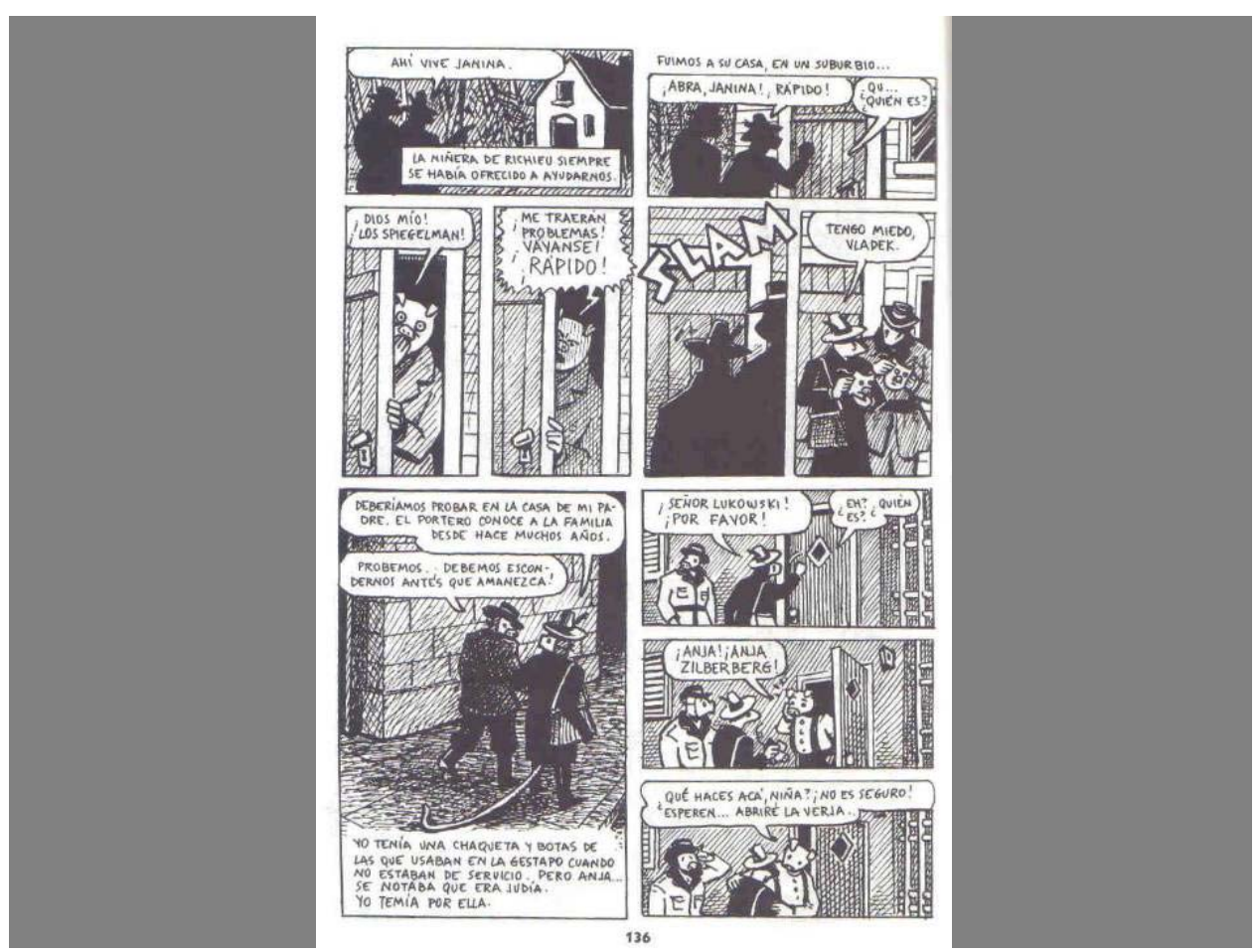

24. A. Spiegelman, Maus, 1973-1986, ratón-perro.

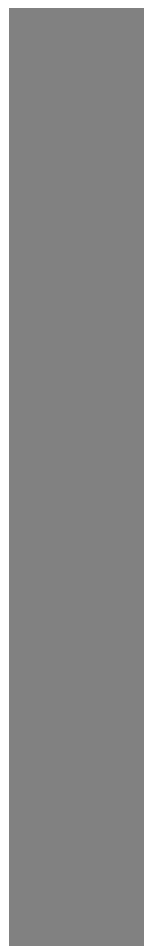

GUANDO ERA CHICO HUBO EN MI BARRIO UN PERRO QUE SE PUSO RABIOSO.

E. PERRO ROPABA ASI UNA Y OTRA YEZ, Y

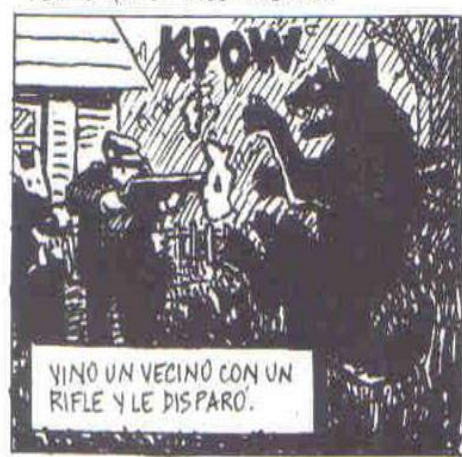
PATALEABA ANTES DE INMOYILIZARSE.

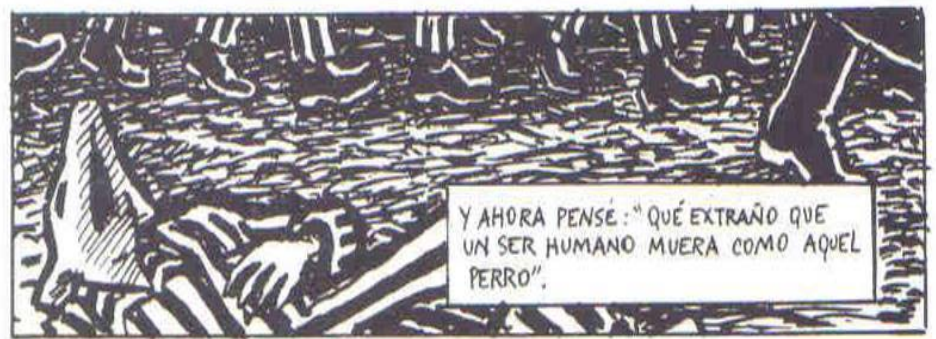

82
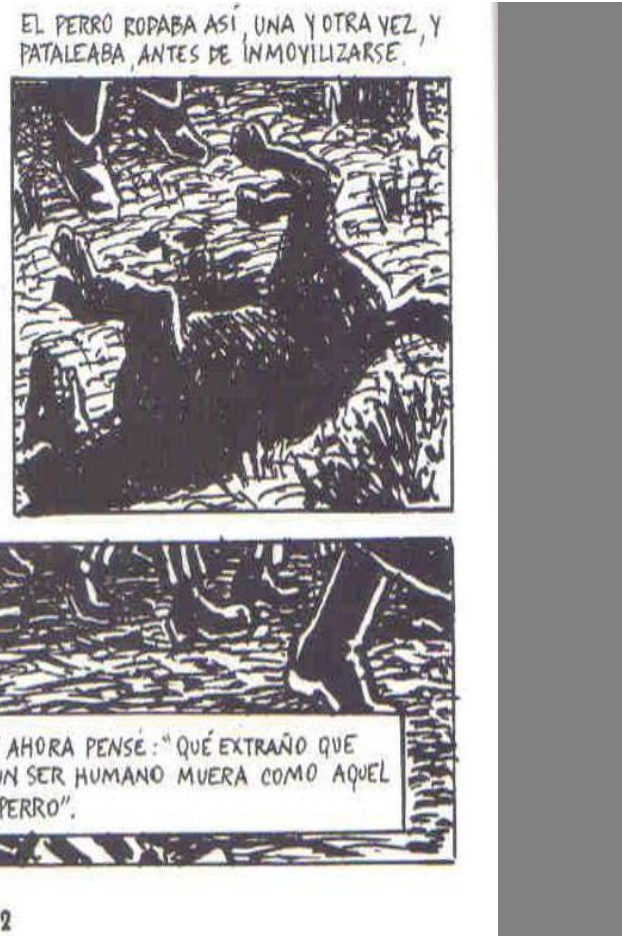
25. A. Spiegelman, Maus, 1973-1986, cámara de gas, y Laocoonte.

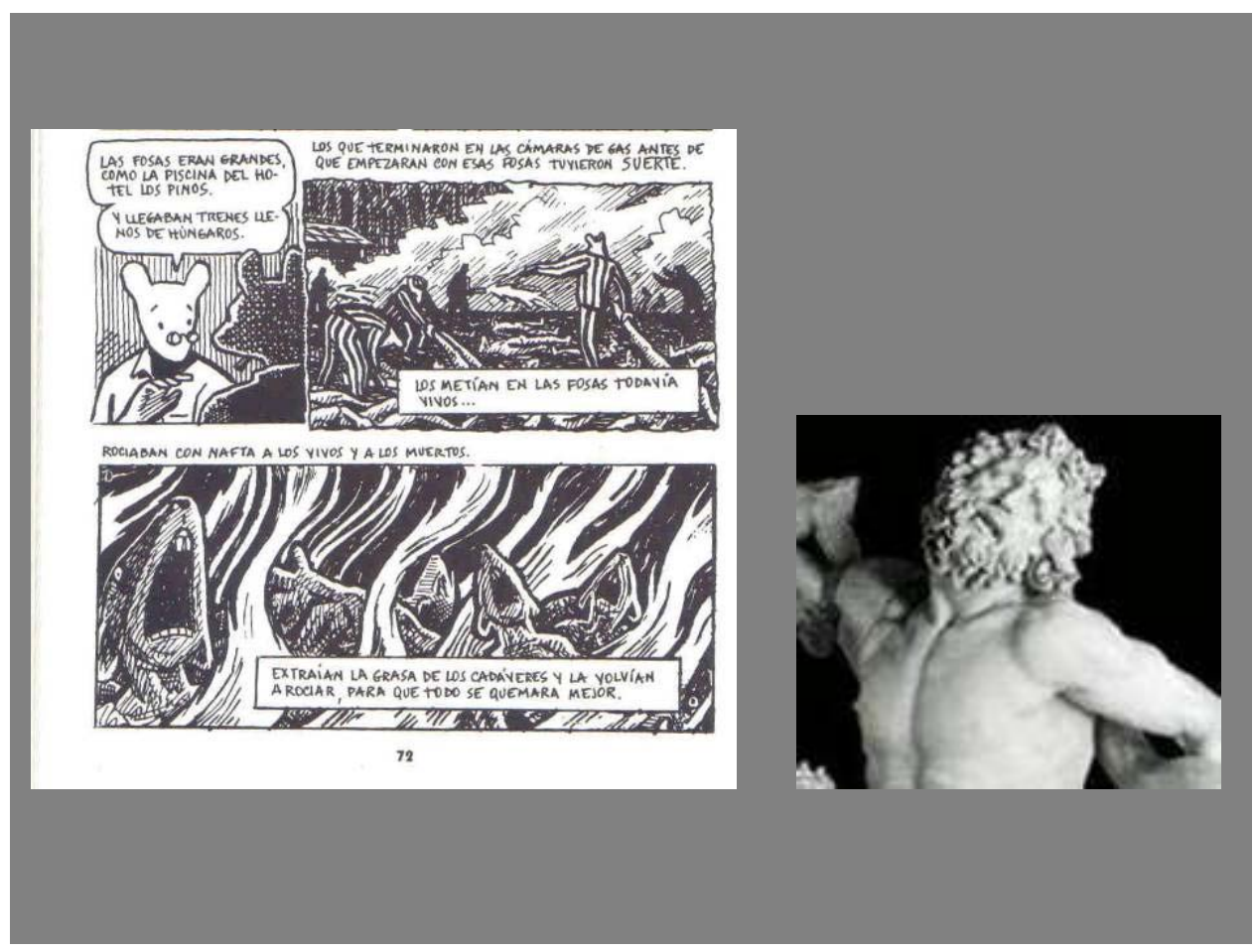

26. A. Spiegelman, Maus, 1973-1986, infierno.

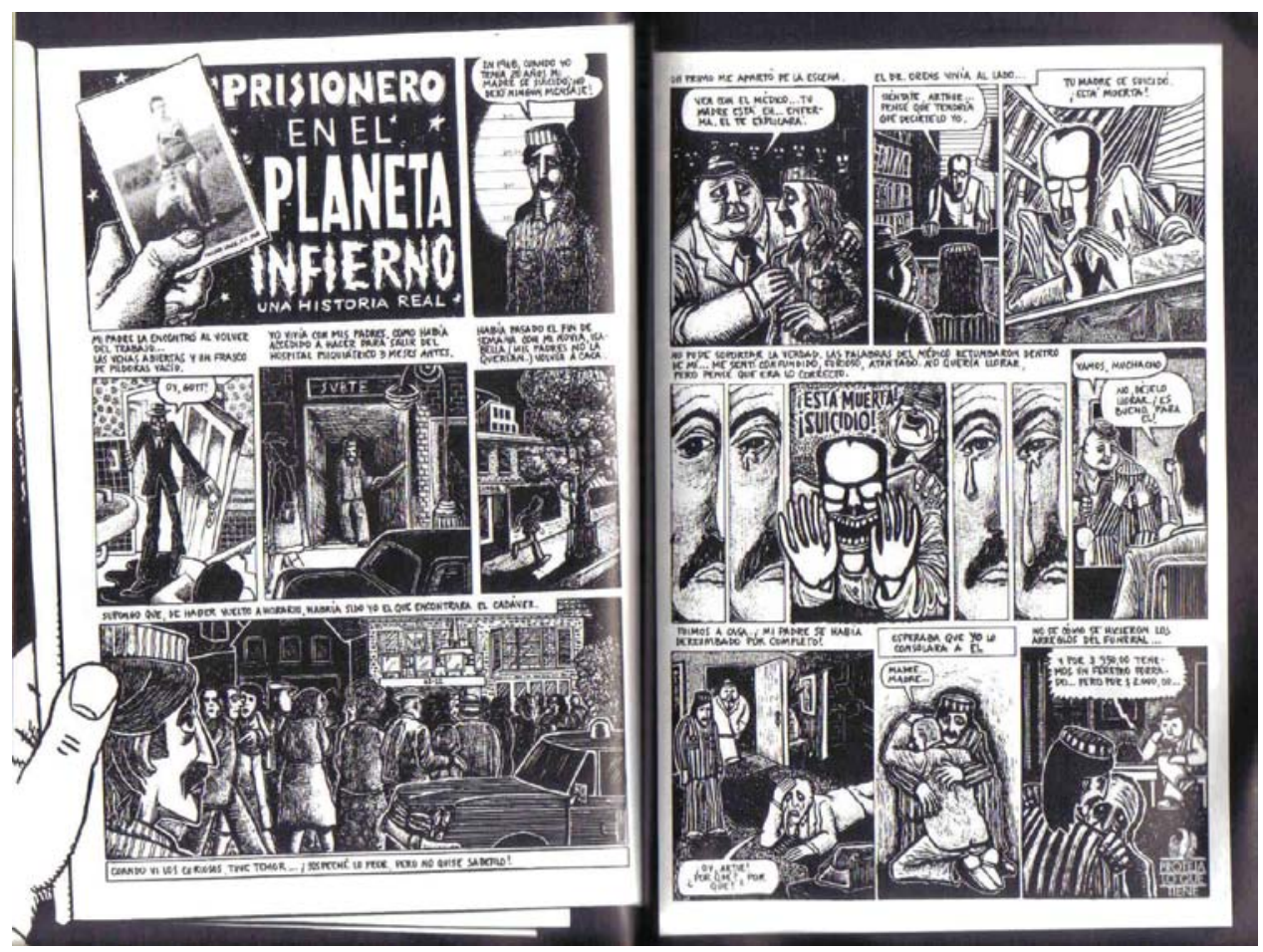


27. A. Spiegelman, Maus, 1973-1986, más infierno.

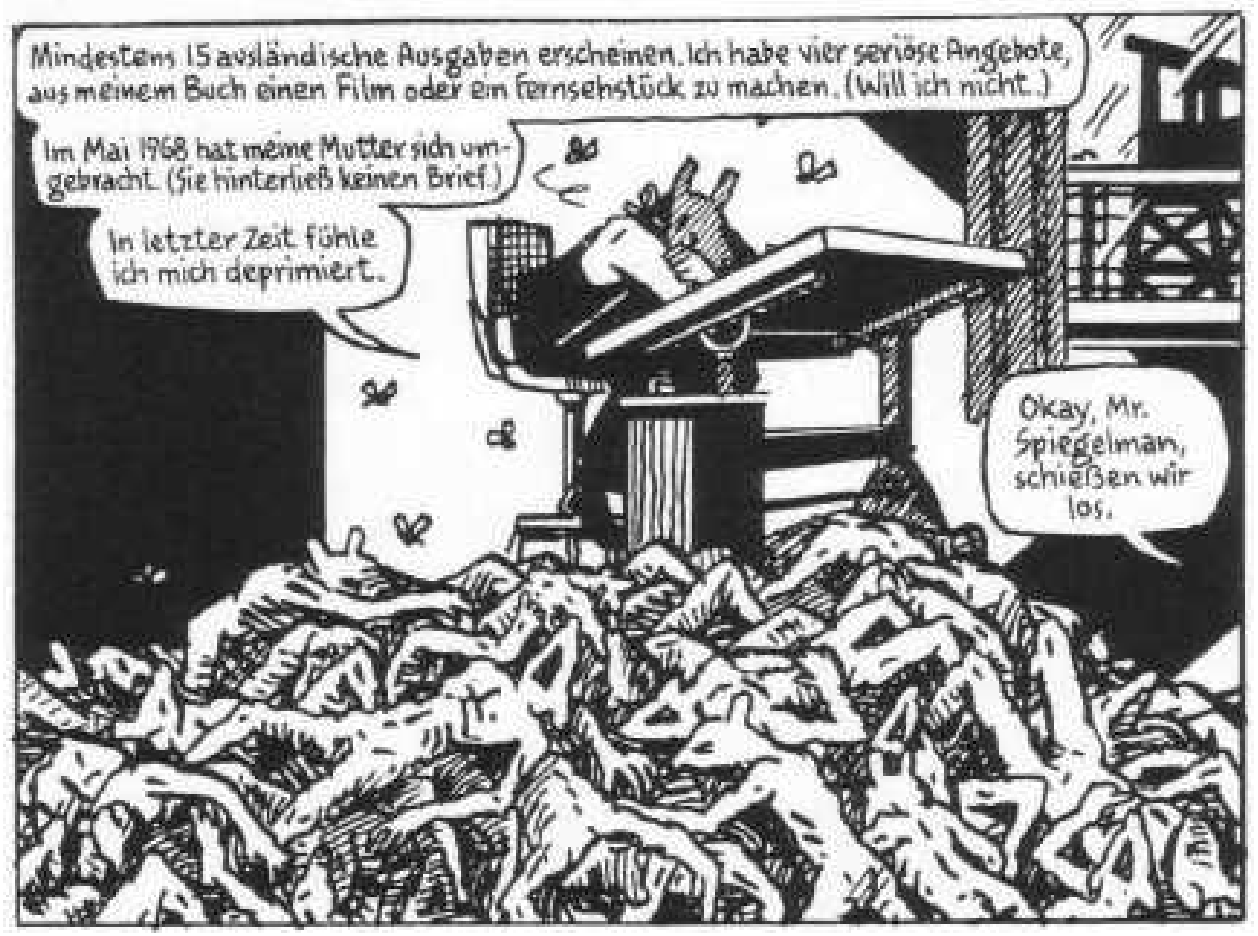

28. A. Spiegelman, Maus, 1973-1986, forma esvástica en el camino.

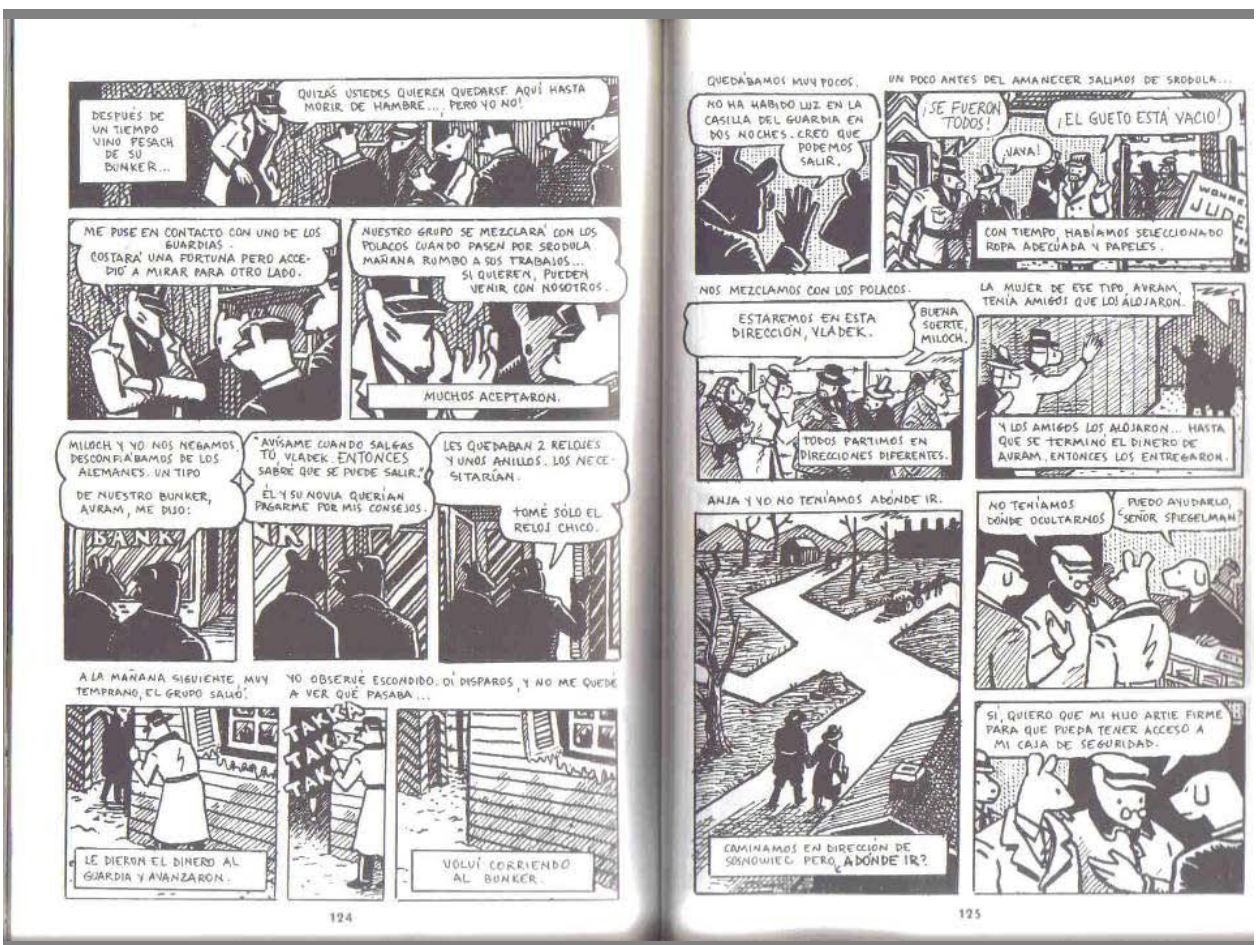


29. A. Spiegelman, Maus, 1973-1986, tapas.

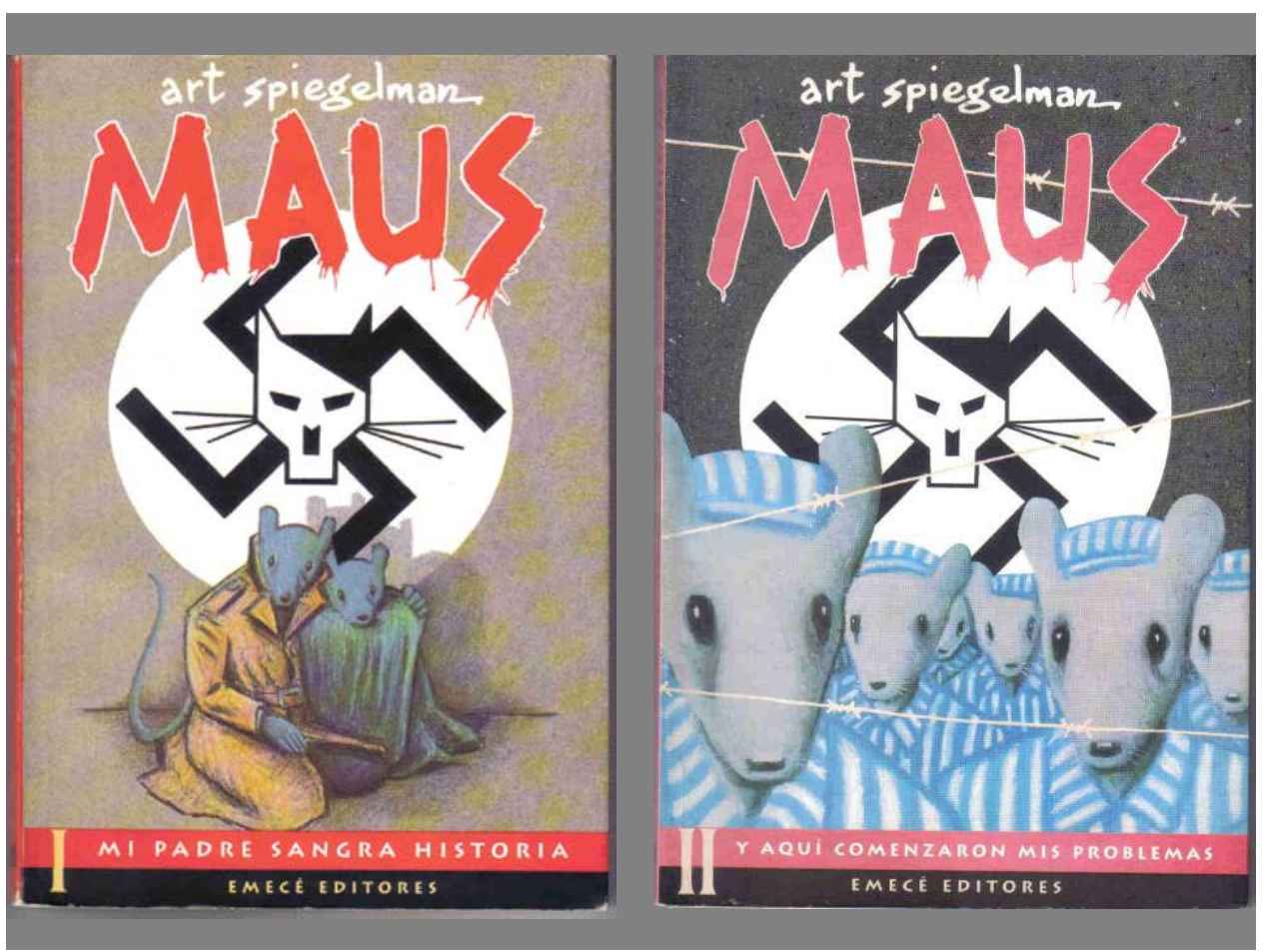

30. A. Spiegelman, Maus, 1973-1986, Título y firmas.

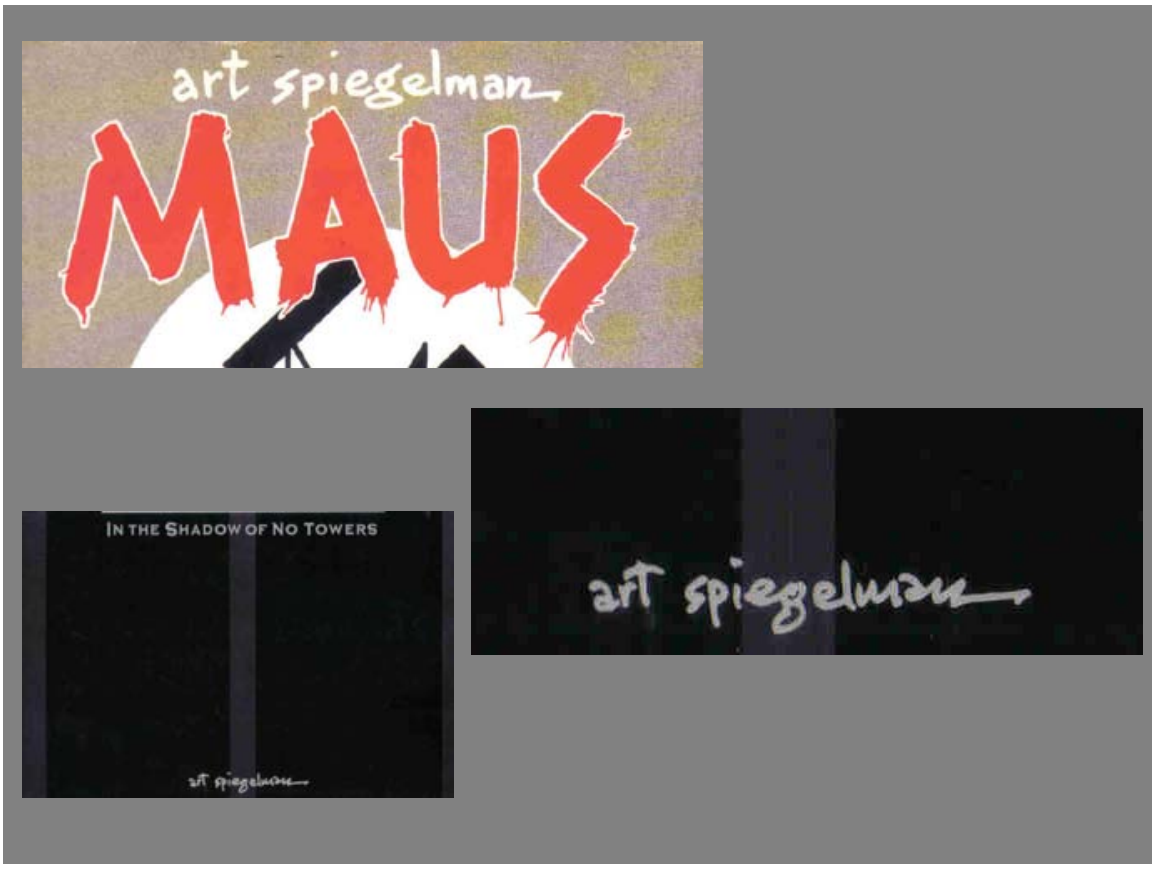


31. A. Spiegelman, In the shadow of no towers, 2004, experimentación formal.

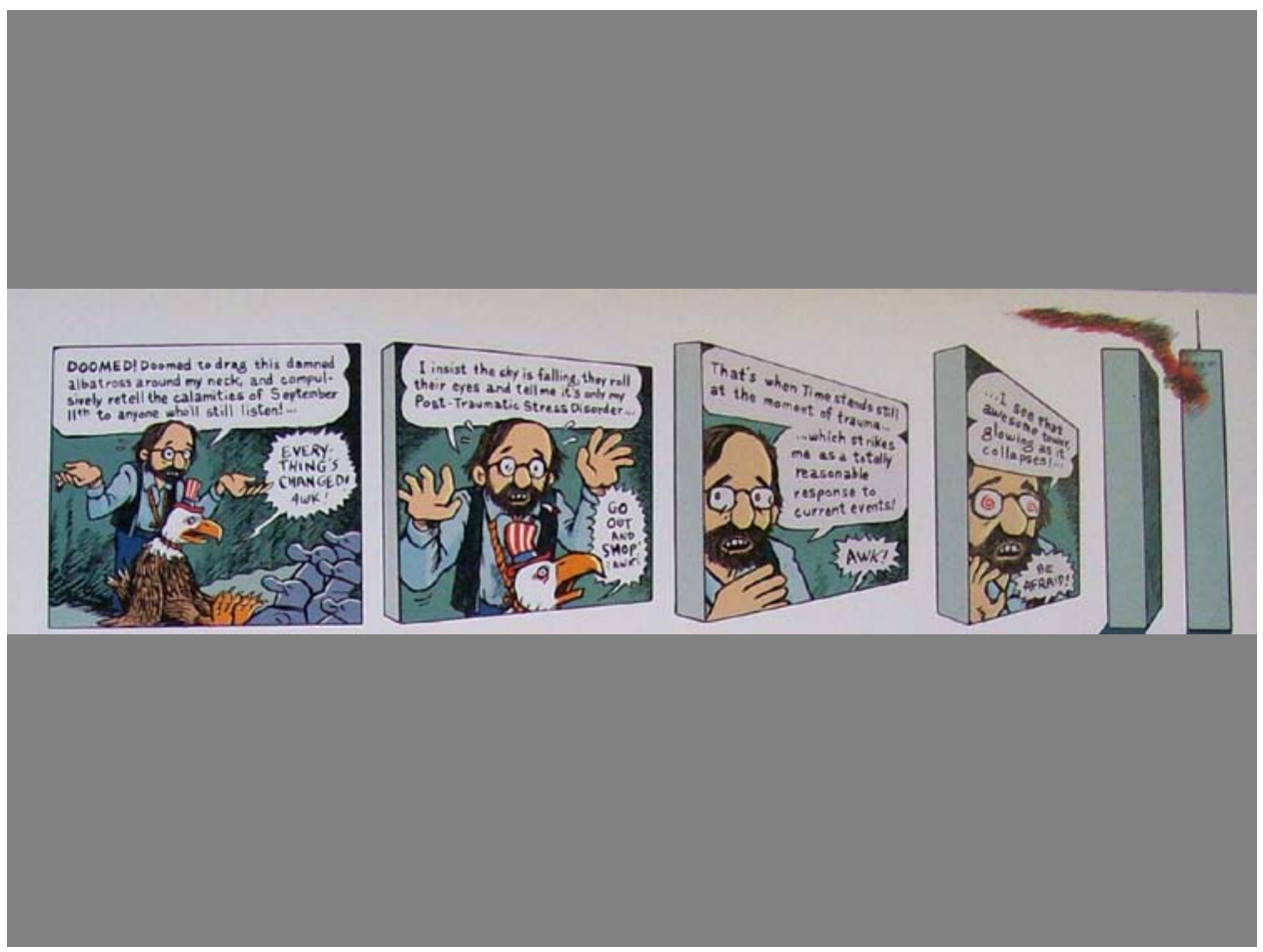

32. A. Spiegelman, In the shadow of no towers, 2004, Art ratón con Al Qaeda y su gobierno.

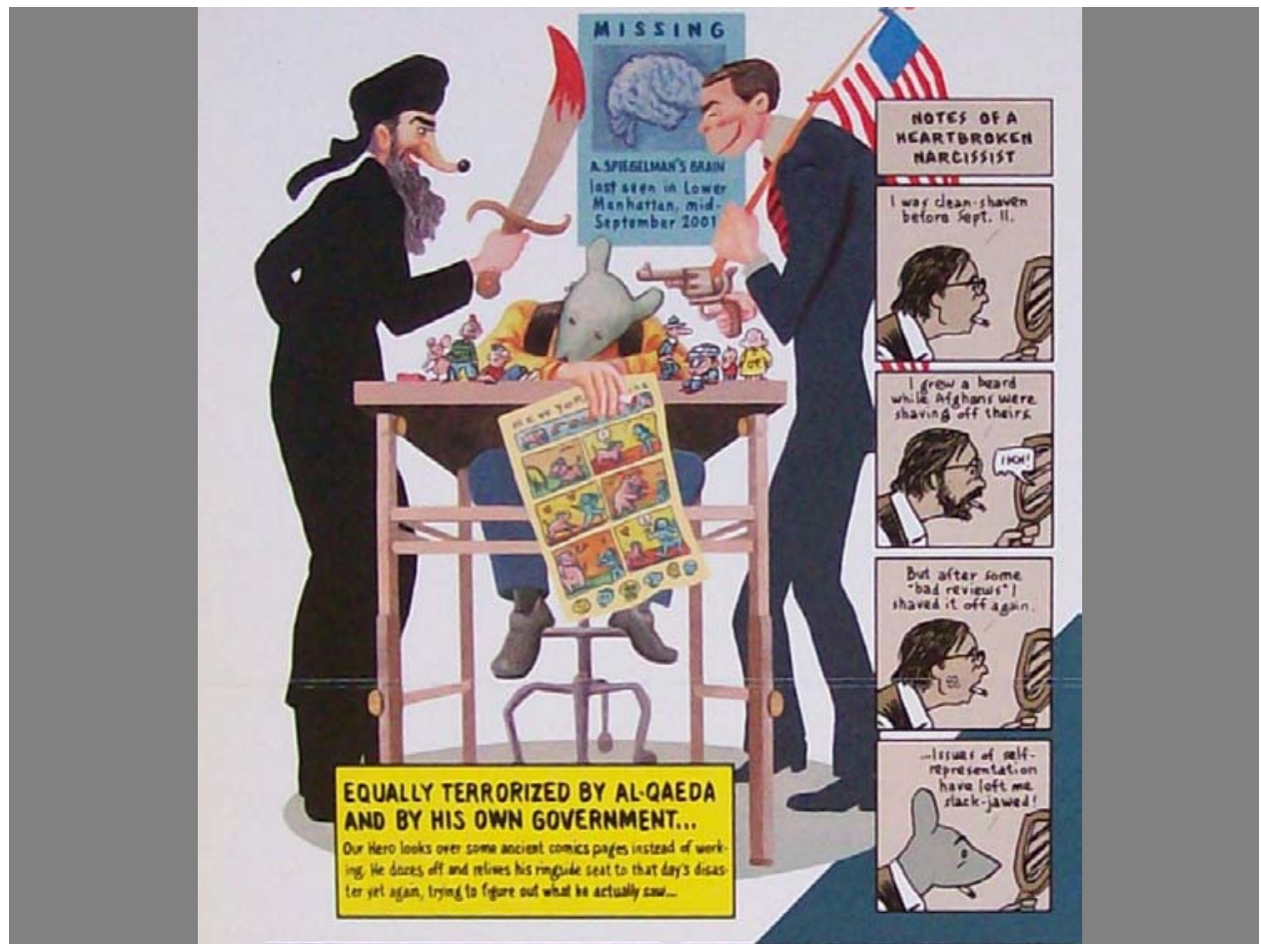


33. A. Spiegelman, In the shadow of no towers, 2004, humo y polvo.

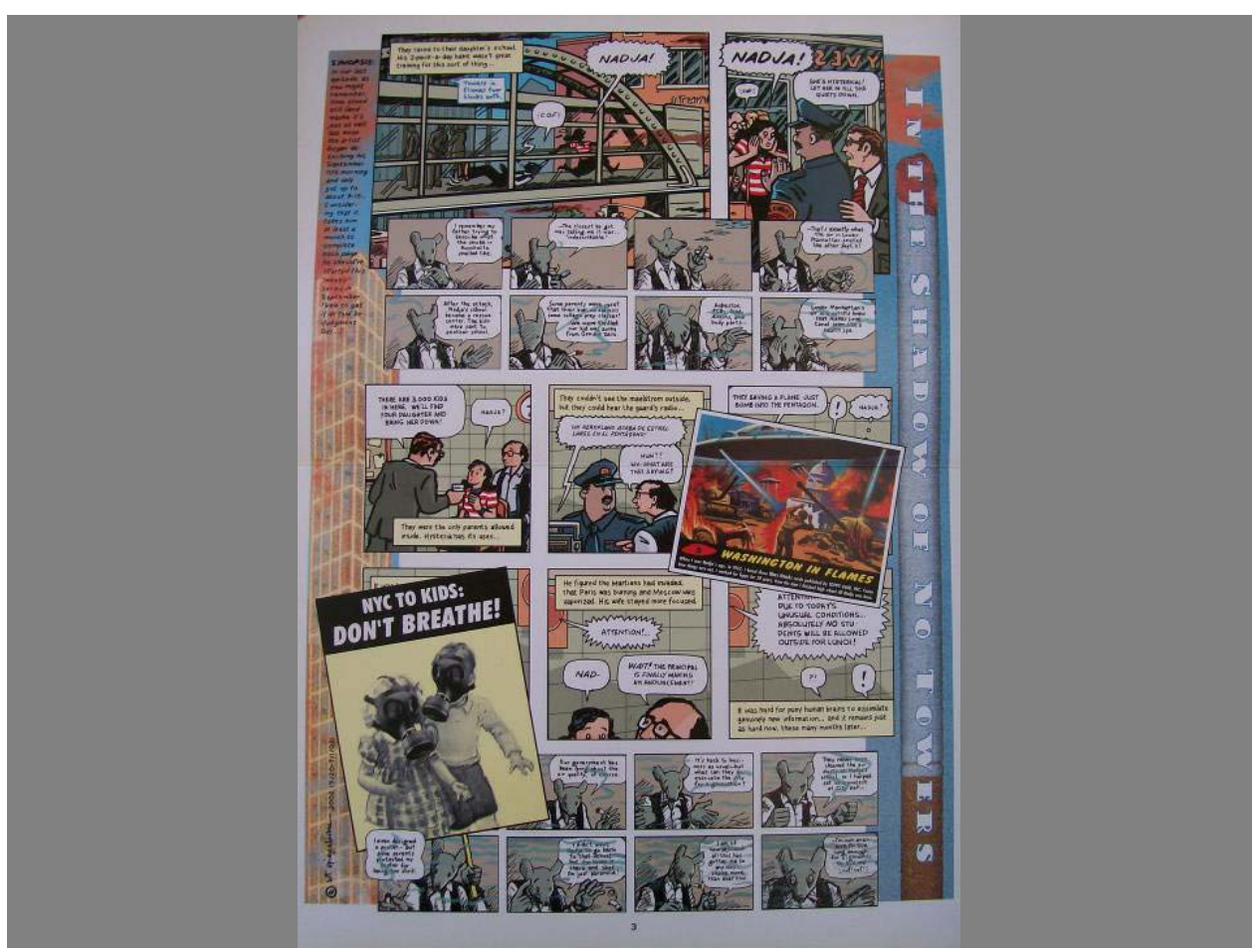

34. A. Spiegelman, In the shadow of no towers, 2004, águila degollada.

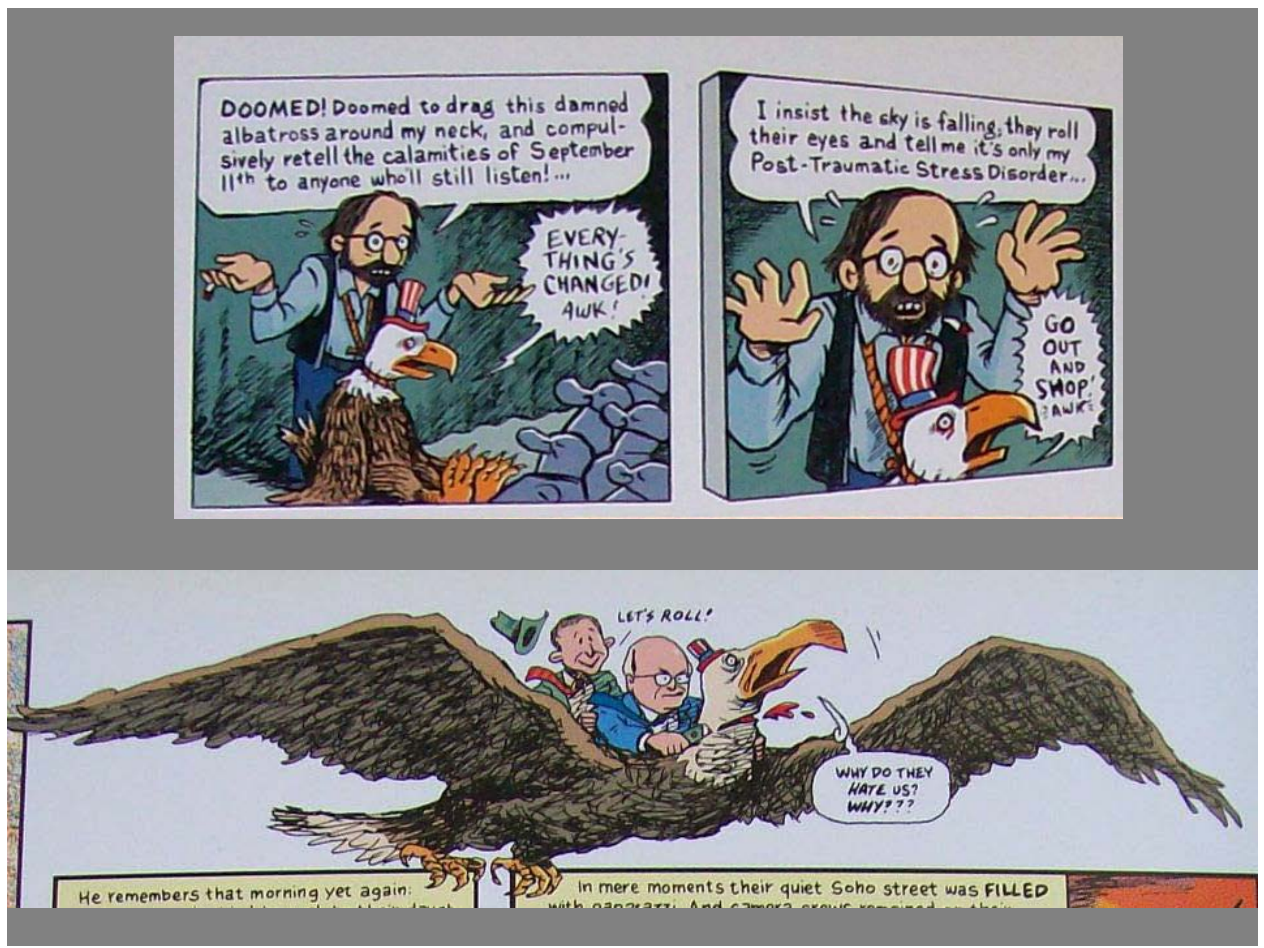


35. A. Spiegelman, In the shadow of no towers, 2004, juego con el gatito.

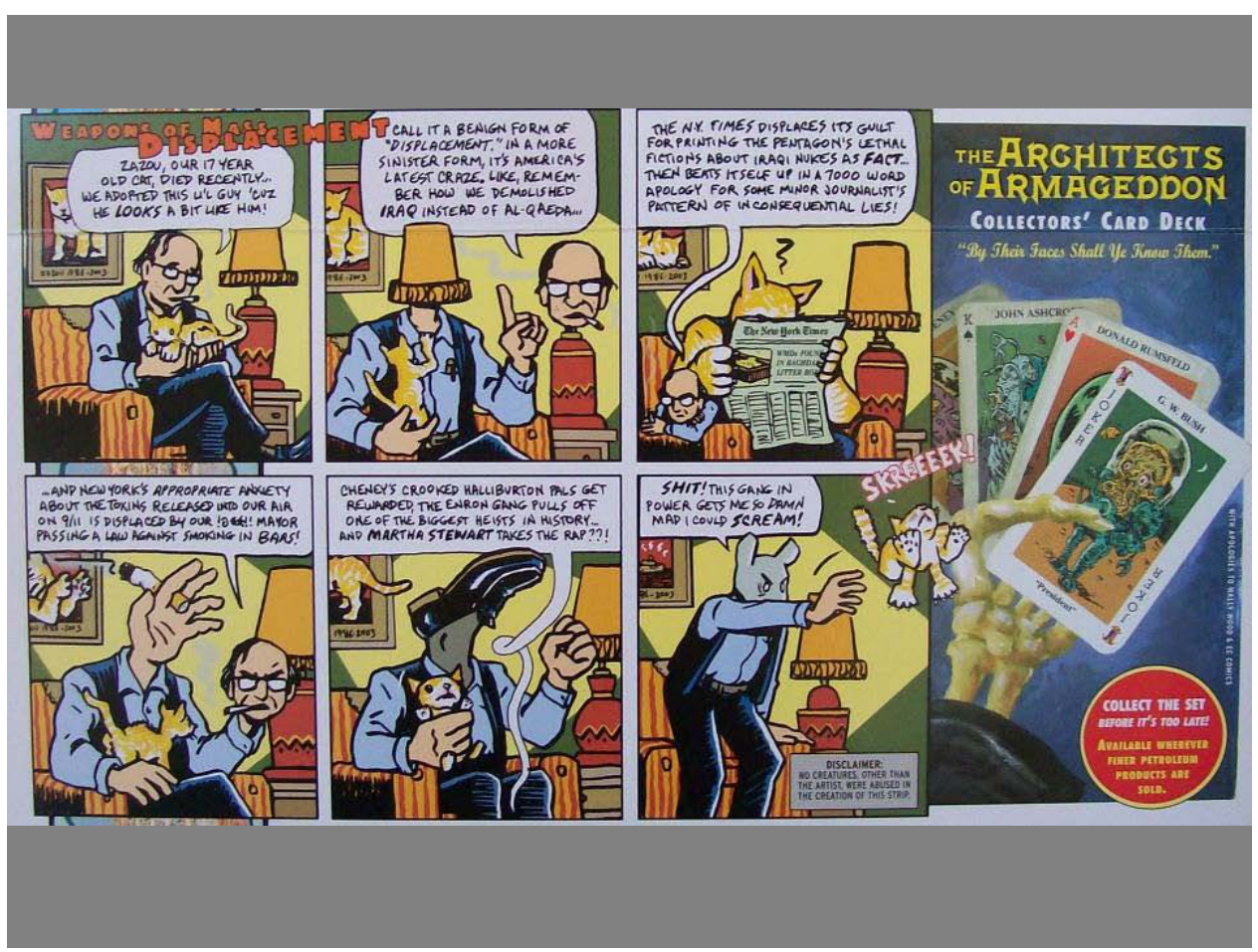

36. A. Spiegelman, In the shadow of no towers, 2004, homenaje a historietas clásicas. Kinder Kids, Happy Hooligan, Little Lady Lovekins, Bringing Up Father.

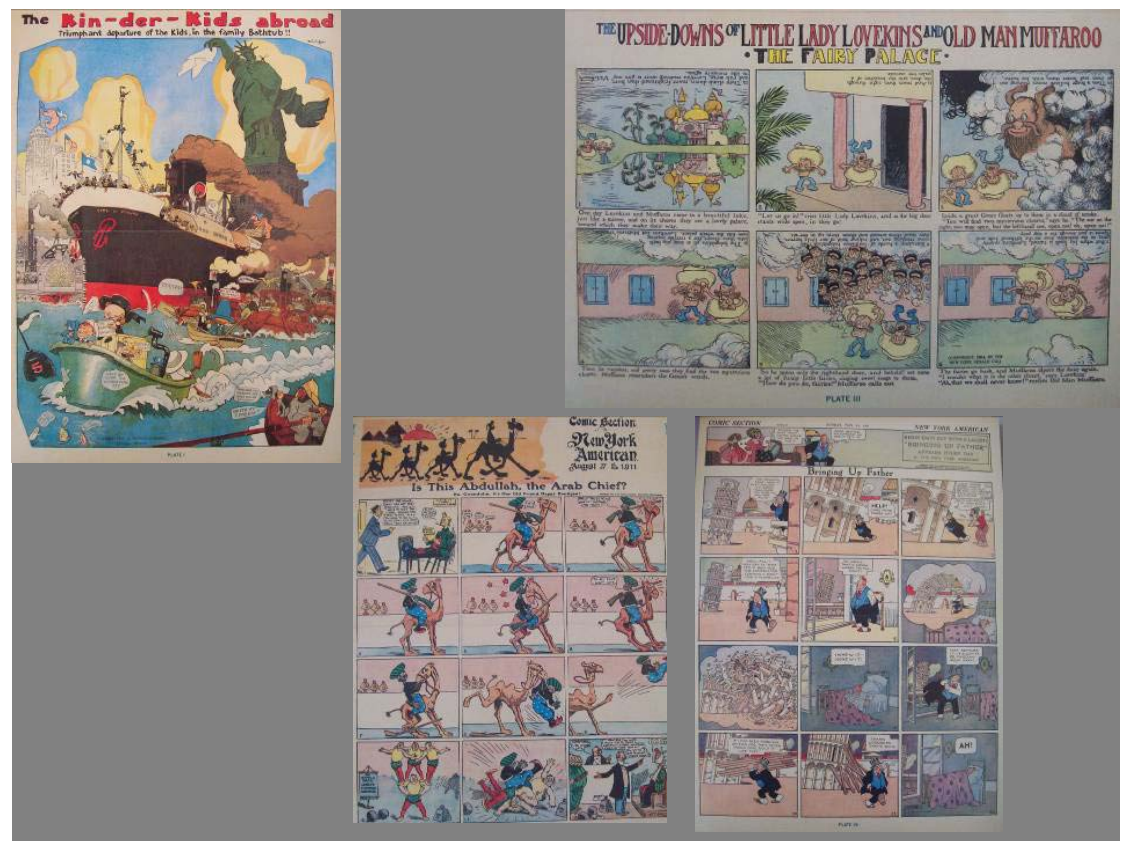


37. A. Spiegelman, In the shadow of no towers, 2004, homenaje a historietas clásicas. Crazy Cat.

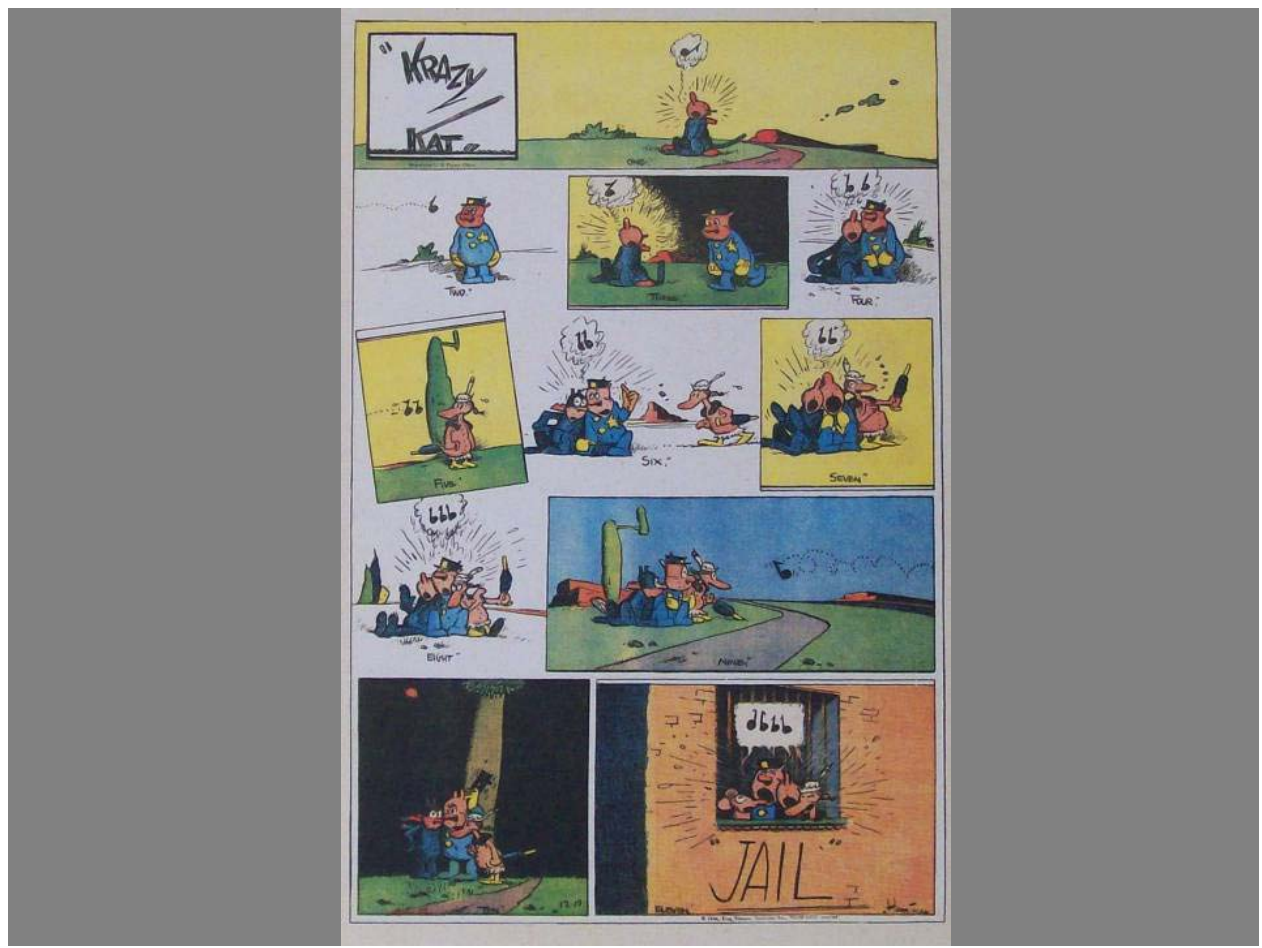

38. Folman y Polonsky, Vals con Bashir, 2009. Perros feroces y sufrientes.

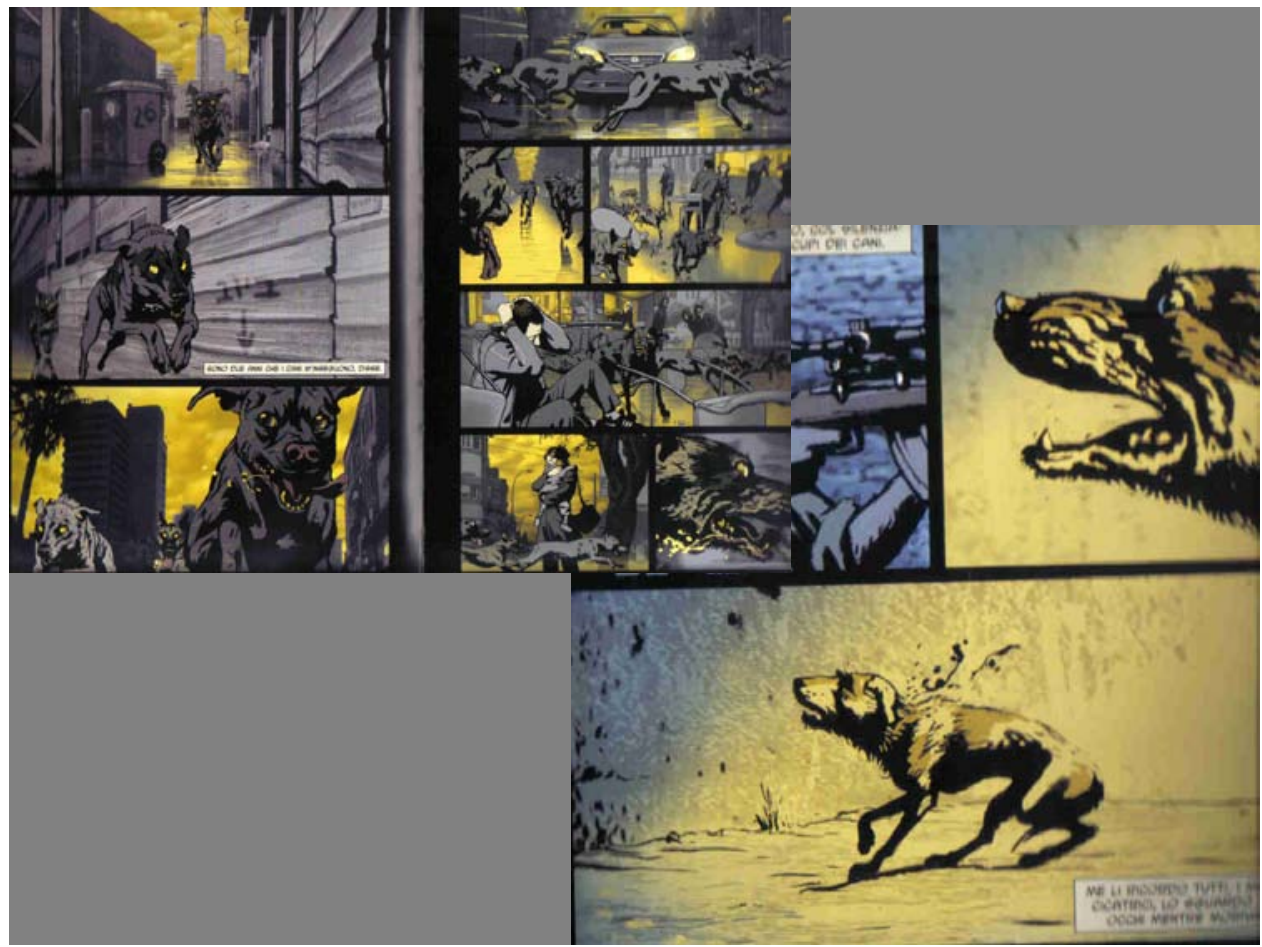


39. Folman y Polonsky, Vals con Bashir, 2009. Caballo muerto.

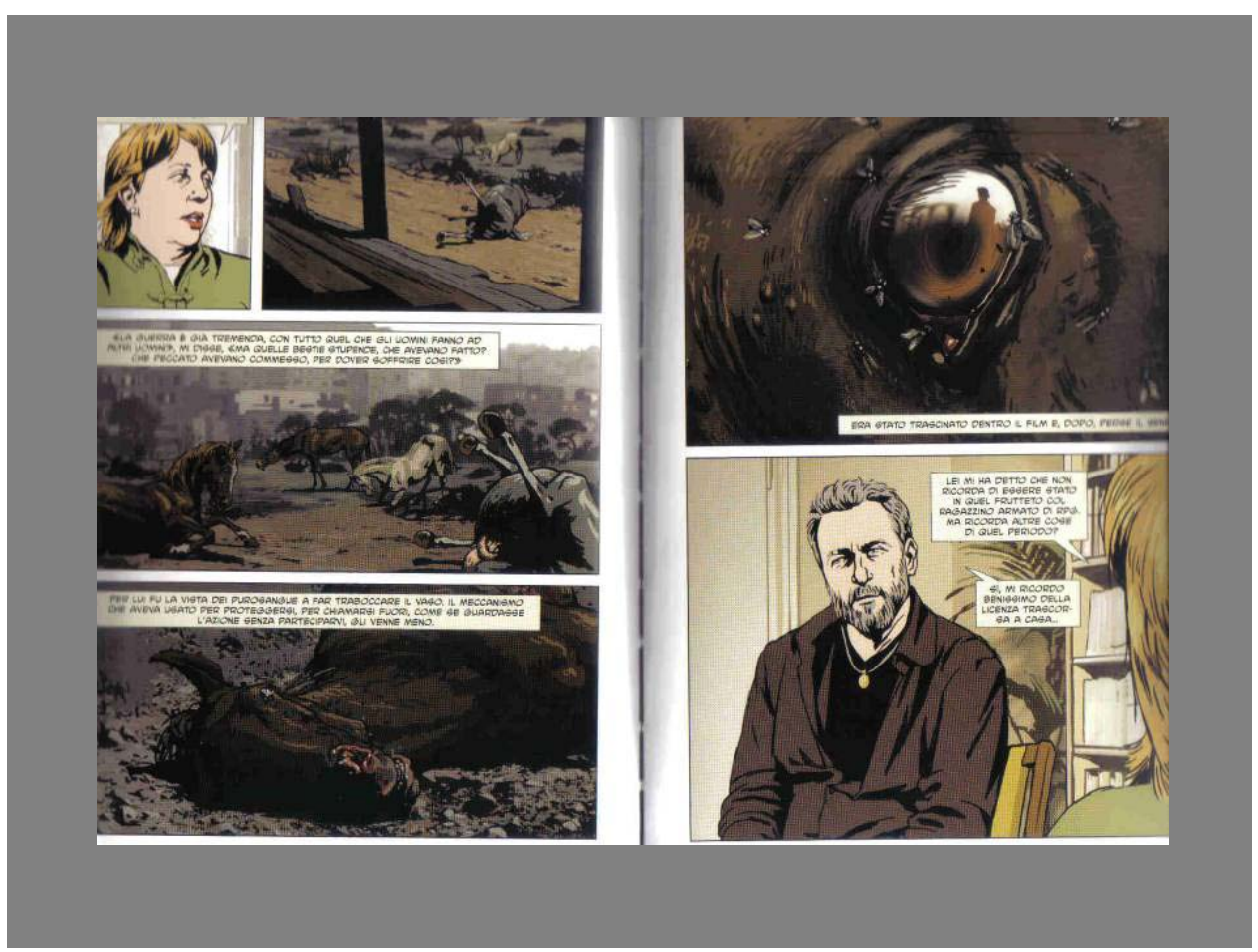

40. Folman y Polonsky, Vals con Bashir, 2009. Perros y cromatismo.

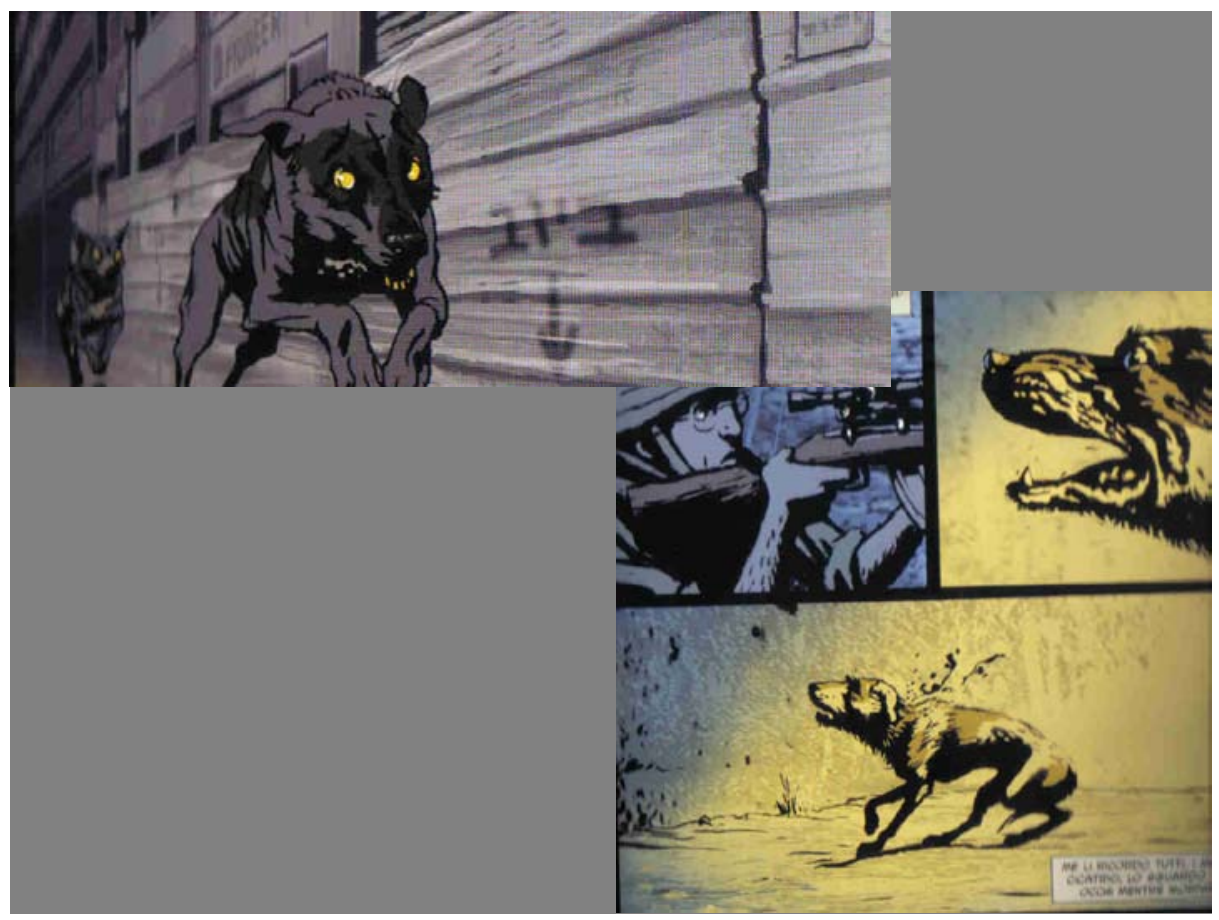


41. Folman y Polonsky, Vals con Bashir, 2009. El camino hacia Sabra y Chatila.

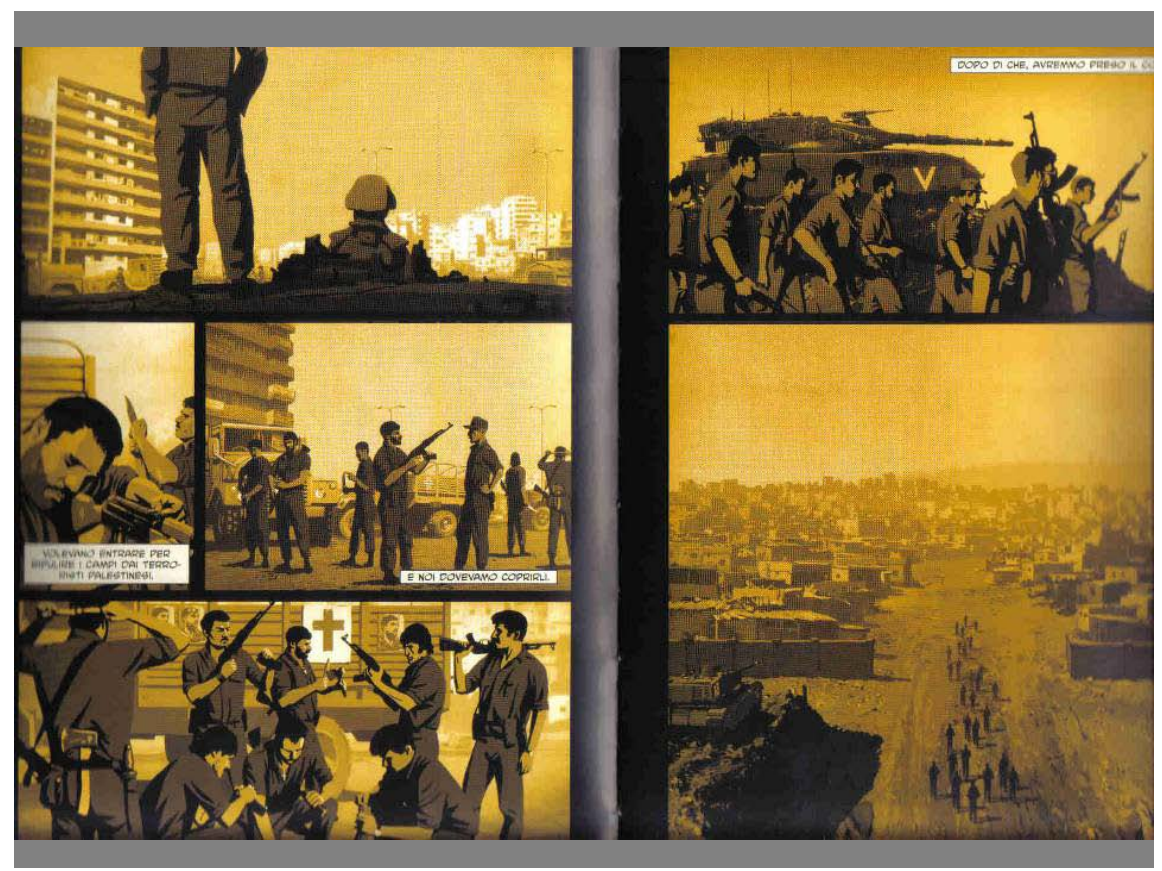

42. Folman y Polonsky, Vals con Bashir, 2009. Sabra y Chatila y mujer sufriente.

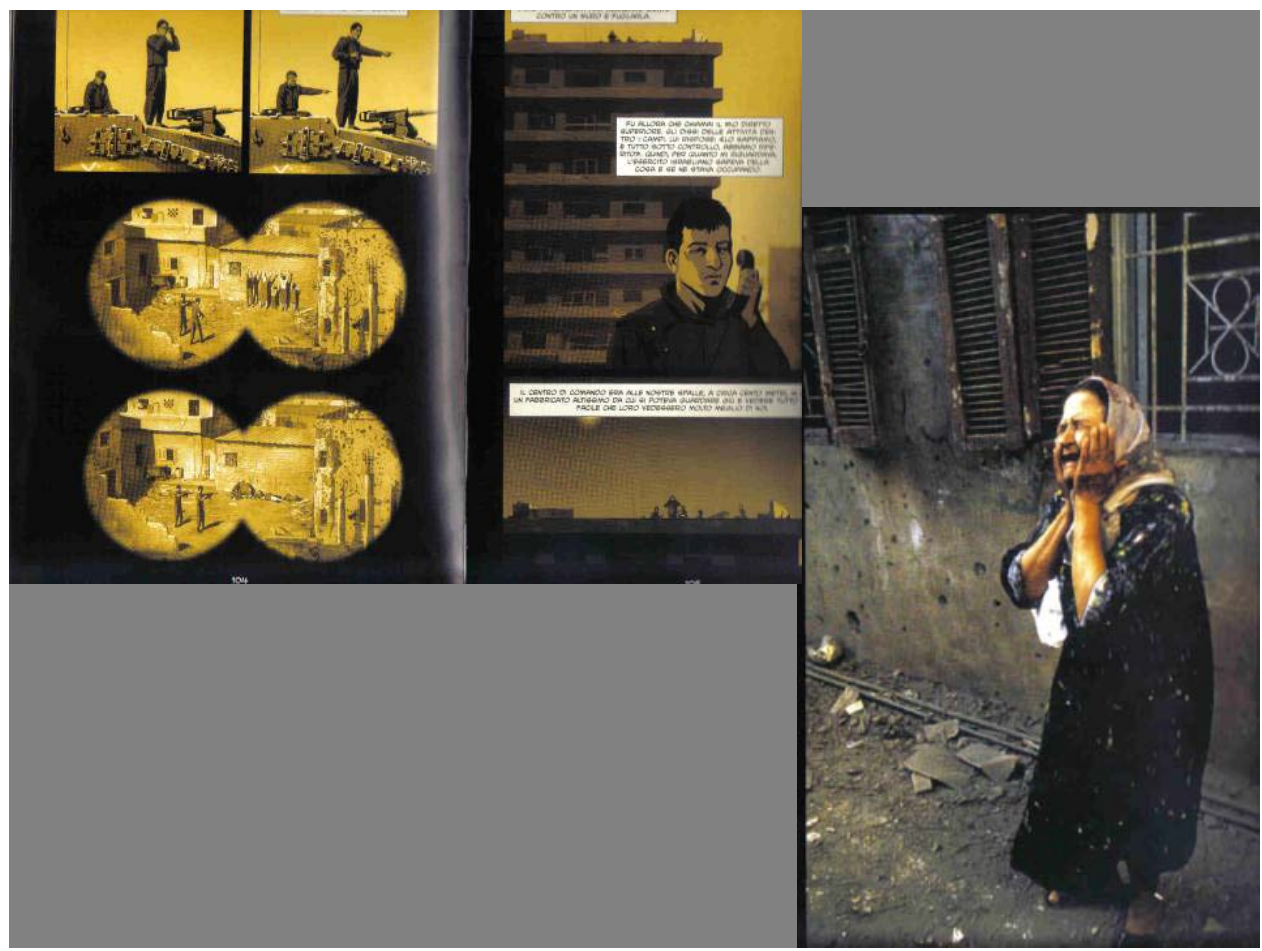


43. Folman y Polonsky, Vals con Bashir, 2009. Niño muerto.

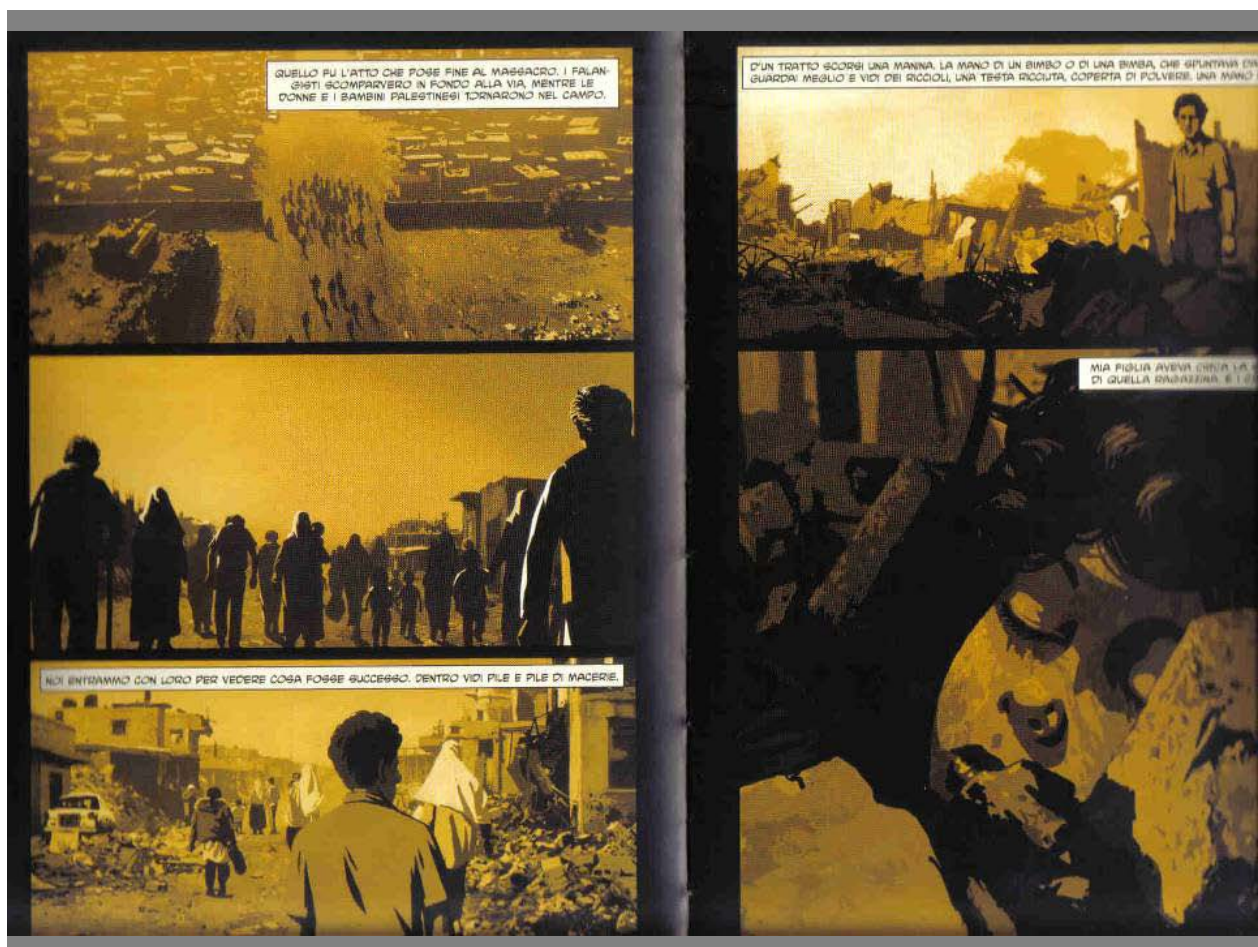

44. Folman y Polonsky, Vals con Bashir, 2009. Fotogramas finales.

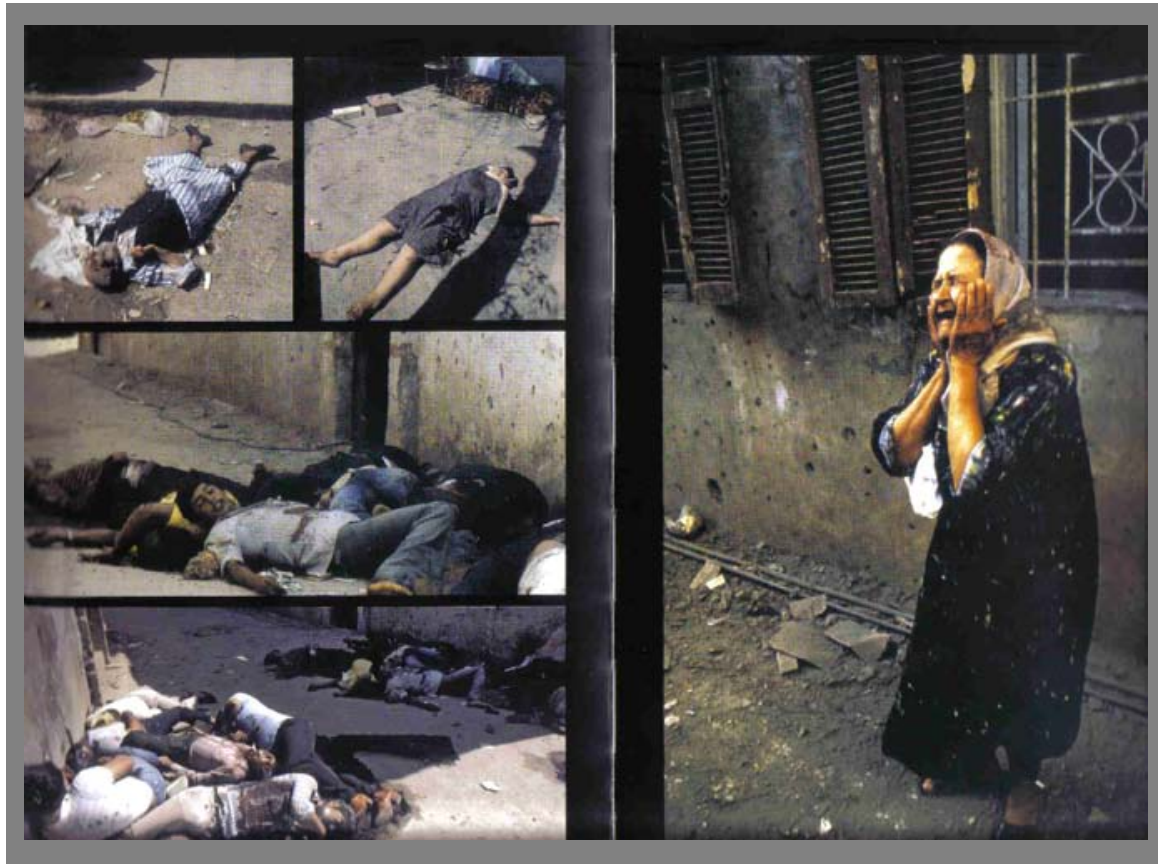


45. Luis Rossell, Alfredo Villar y Jesús Cossio, Rupay, 56.

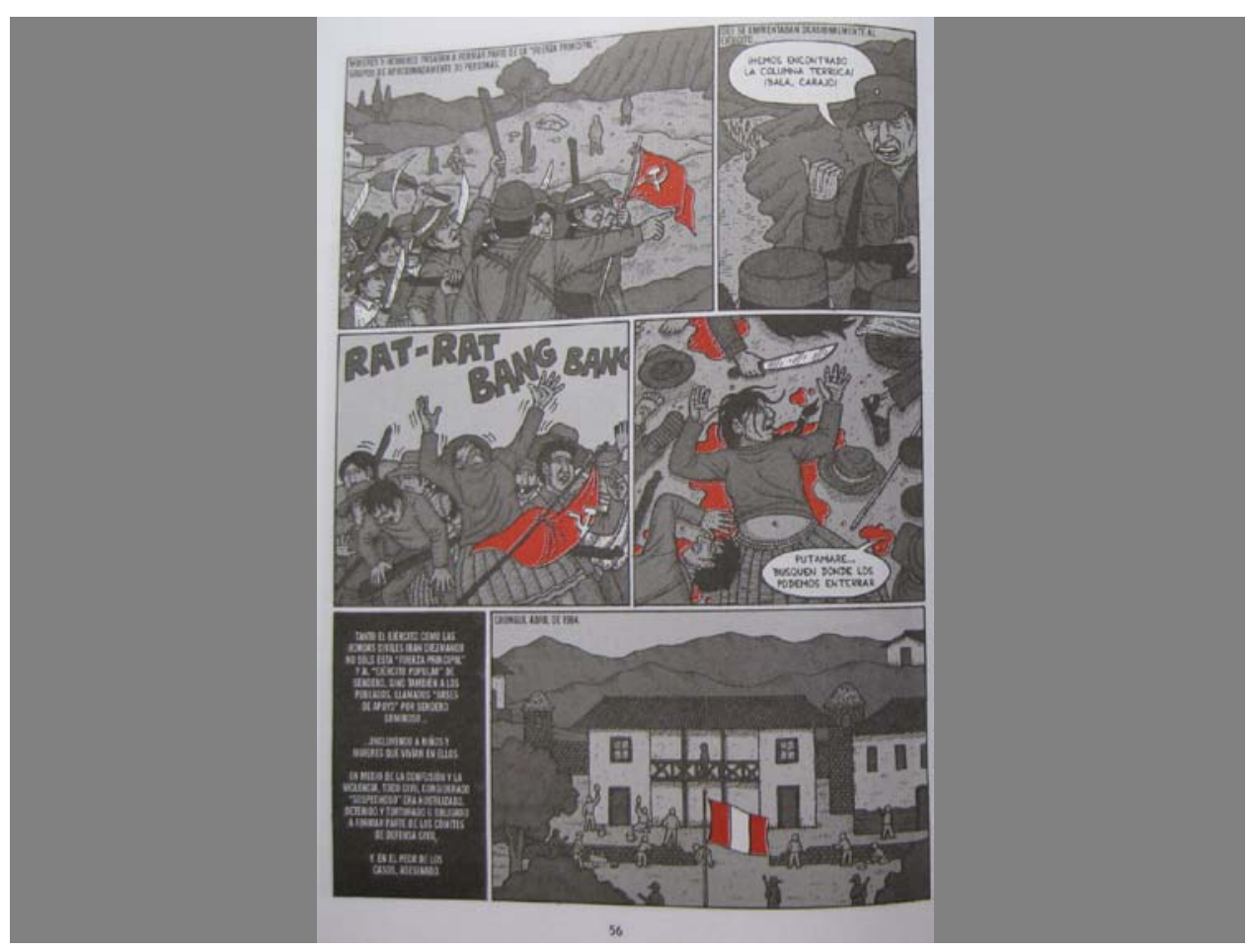

